\title{
Estudo taxonômico das espécies nativas de Hypericum L. (Hypericaceae) no Estado do Paraná, Brasil ${ }^{1}$
}

\author{
Simone Rodrigues Slusarski ${ }^{2,4}$, Armando Carlos Cervi ${ }^{3}$ e Olavo Araújo Guimarães ${ }^{3}$
}

Recebido em 7/01/2005. Aceito em 29/08/2006

\begin{abstract}
RESUMO - (Estudo taxonômico das espécies nativas de Hypericum L. (Hypericaceae) no Estado do Paraná, Brasil). É apresentado o estudo taxonômico de Hypericum no Estado do Paraná. Este gênero inclui cerca de 350 espécies nas regiões temperadas e subtropicais de todo o mundo. No Brasil, ocorrem 17 espécies, 12 das quais confirmadas para o Estado do Paraná, além de três subespécies, distribuídas em todas as regiões fitogeográficas do Estado, principalmente na estepe gramíneo-lenhosa. Apresenta-se chave de identificação dos táxons, descrições, ilustrações, dados ecológicos e de distribuição geográfica.
\end{abstract}

Palavras-chave: Brasil, Estado do Paraná, Hypericum, taxonomia

\begin{abstract}
Taxonomy of native species of Hypericum L. (Hypericaceae) in Paraná, Brazil). A taxonomic study of the genus Hypericum L. (Hypericaceae) in the state of Paraná was carried out. This genus includes about 350 species, mostly cosmopolitan, occurring in temperate and subtropical regions worldwide. Seventeen species are found in Brazil, with twelve species and three subspecies in Paraná, in all phytogeographic regions of the state, mainly in grasslands. An identification key for the taxa, descriptions, illustrations and data on geographic distribution and ecology are provided.
\end{abstract}

Key words: Brazil, Paraná State, Hypericum, taxonomy

\section{Introdução}

Inicialmente, o gênero Hypericum L. fez parte da família Hypericaceae nom. cons., conceito aceito por vários autores como Saint Hilaire (1805), Reichardt (1878) e Takhtajan (1980), entre outros. Entretanto, Engler (1893) incluiu o gênero na família Guttiferae, nomem conservadum para Clusiaceae, dividindo esta em cinco subfamílias, dentre as quais Hypericoideae. Esta nova concepção foi aceita por vários autores como Wettstein (1944), Barroso et al. (1978), Cronquist (1981; 1988), Judd et al. (1999) e Robson (1990). Por outro lado, autores como Lawrence (1977), Rodríguez Jiménez (1980) e, mais recentemente, APG II (2003), mantêm o gênero Hypericum em Hypericaceae.

O gênero Hypericum inclui cerca de 250 espécies distribuídas nas regiões temperadas e subtropicais (Cronquist 1981). No Brasil, ocorrem 17 espécies (Reichardt 1878) principalmente nas Regiões Sul e Sudeste.
O objetivo deste trabalho é o levantamento das espécies de Hypericum ocorrentes no Estado do Paraná e a análise de sua distribuição geográfica.

\section{Material e métodos}

Foram realizadas coletas casuais no período de março/2001 a dezembro/2002, procurando abranger todas as regiões fitogeográficas do Estado. Em campo, foram observadas as características vegetativas e reprodutivas relevantes para o gênero. Exsicatas foram analisadas mediante empréstimo ou consulta aos seguintes herbários: EFC, FLOR, FUEL, HBR, HUCP, HUM, ICN, MBM, RB, RFA, SP e UPCB, citados por sua sigla internacional, conforme Holmgren \& Holmgren (2006). Além destes, foram revisados os herbários da Faculdade Espírita, Curitiba, Paraná, e da Universidade Estadual de Ponta Grossa, Paraná, cujas siglas, não oficiais, são HSIE e HUEPG, respectivamente.

\footnotetext{
Dissertação de Mestrado da primeira Autora, Universidade Federal do Paraná

2 Ecologia de Ambientes Aquáticos Continentais da Universidade Estadual de Maringá, Av. Colombro 5790 - PEA, Bloco G-90, $87020-900$ Maringá, PR, Brasil

3 Universidade Federal do Paraná, Departamento de Botânica, Curso de Pós-Graduação em Botânica, C. Postal 19.031, 81531-980 Curitiba, PR, Brasil

4 Autor para correspondência: simone_slusarski@hotmail.com
} 
Para a identificação das espécies foram utilizadas chaves analíticas de Reichardt (1878), Smith (1958), Rodríguez Jiménez (1980), Robson (1990) e Bittrich (2003), bem como consultas às descrições originais. As descrições do gênero e espécies basearam-se em exemplares coletados no Estado do Paraná. A terminologia empregada na distribuição geográfica das espécies segue o trabalho de Roderjan et al. (1993), utilizando-se as seguintes abreviações: FOD (Floresta Ombrófila Densa), FOM (Floresta Ombrófila Mista) e FES (Floresta Estacional Semidecidual).

\section{Resultados e discussão}

\section{Hypericum L., Sp. pl.: 783. 1753.}

Ervas anuais ou perenes, com base lignificada ou não, subarbustos ou arbustos, eretos ou decumbentes; caule cilíndrico na base e quadrangular na parte superior, esfoliante ou não, de coloração parda, pardoavermelhada, marrom ou marrom-avermelhada; folhas isomórficas ou heteromórficas, sésseis, simples, sem estípulas, opostas ou, menos comumente, verticiladas, glabras, lineares, elípticas, elíptico-oblongas, oblongas, oblongo-lanceoladas, lanceoladas, ovaladas, ovaladooblongas, ovalado-triangulares, ovalado-deltóides, triangular-lanceoladas, semi-circulares ou suborbiculares, coriáceas, subcoriáceas, cartáceas ou membranáceas, pálidas, avermelhadas ou verdes na face abaxial, ápice agudo, acuminado, obtuso ou arredondado, base livre, parcial ou completamente conata, truncada, cuneada, subcordada, cordada, arredondada, convexa ou decorrente-amplexicaule, margens planas ou revolutas, colenquimatosas ou não, glândulas punctiformes em ambas as faces ou somente na face abaxial, venação pinada. Inflorescência uni ou multiflora, cimas dicotômicas terminais com ramificações laterais, pseudodicotômicas ou axilares, brácteas ovaladas, triangulares, oblongas, linearlanceoladas ou lanceoladas, ápice agudo, glândulas punctiformes; flores pediceladas, bissexuadas; cálice persistente e ereto no fruto, com 5 sépalas fundidas, iguais, subiguais ou desiguais entre si, coriáceas, lanceoladas, elípticas, oblongas ou ovaladas, ápice agudo, subacuminado ou obtuso, margens inteiras, imbricadas ou não, glândulas punctiformes marginais; corola actinomorfa, 5 pétalas livres, de coloração amarela ou alaranjada, actinomorfas, membranosas, obovadas, obovado-oblongas, oblongas, oblongolanceoladas ou lanceoladas, ápice agudo ou subagudo, apículo terminal, subterminal ou ausente, margens inteiras, glândulas punctiformes marginais ou ausentes; estames $8-\infty$, livres ou soldados formando um anel, ou 3-5 fasciculados, com número variável de estames por fascículo, filetes livres ou pouco unidos, glabros, anteras introrsas, dorsifixas, abertura longitudinal, amarelas; ovário súpero, subgloboso, globoso ou ovóide, glabro, 1-locular, 3-5 carpelar, placentação parietal, $\infty$-rudimentos seminais, estiletes 3-5, estigmas capitados ou clavados. Fruto cápsula septicida, 3-5 valvar, ovóide, oblonga, cilíndrica ou elipsóide, marrom ou negra, de comprimento menor, igual ou maior ao das sépalas. Sementes numerosas, oblongas, amarelas ou negras, reticuladas.

Chave para a identificação dos táxons de Hypericum no Estado do Paraná, Brasil

1. Estiletes $3(-4)$

2. Folhas lineares, $2,0-3,0 \mathrm{~cm}$ compr.

10. H. piriai

2. Folhas não lineares, $0,6-1,7 \mathrm{~cm}$ compr.

3. Folhas membranáceas, perpendiculares ao caule, ápice obtuso ou arredondado, base arredondada ou convexa

9. H. mutilum subsp. mutilum

3. Folhas coriáceas, eretas, ápice agudo ou obtuso, base truncada, convexa, cordada ou subcordada

4. Folhas isomórficas, todas estreitas, ou heteromórficas, incluindo lanceoladas, ovaladas ou ovalado-triangulares; inflorescências em cimas terminais alongadas com ramos pouco folhosos; flores $0,8-1,0 \mathrm{~cm}$ diâm 13. H. ternum

4. Folhas isomórficas, ovaladas, ovalado-triangulares, triangulares, elípticas ou lanceoladas; inflorescências em cimas terminais bastante folhosas; flores 0,5-3,0 cm diâm.

5. Folhas largamente ovaladas, ovalado-triangulares ou ovalado-oblongas, base cordada; flores 0,5-3,0 cm diâm. 5. H. cordatum subsp. cordatum

5. Folhas elípticas, oblongas ou triangular-lanceoladas, base subcordada; flores 0,5-1,5 cm diâm. 6. H. cordatum subsp. kleinii 
1. Estiletes (4-)5

6. Folhas com base de $2 / 3$ a completamente conatas

7. Folhas coriáceas, com margens colenquimatosas escuras

4. H. connatum

7. Folhas cartáceas, sem margens colenquimatosas escuras

2. H. caprifoliatum

6. Folhas livres ou com a base apenas até $1 / 3$ conata

8. Base das folhas decorrente e amplexicaule

3. H. carinatum

8. Base das folhas não decorrente e nem amplexicaule

9. Folhas perpendiculares ao caule, não imbricadas

10. Folhas ovaladas ou elípticas, $1,0-3,3 \times 1,0-2,4 \mathrm{~cm}$

12. H. teretiusculum

10. Folhas lanceoladas a elípticas, oblongas ou ovalado-oblongas, 1,2-6,2×0,2-1,0 cm

11. Folhas cartáceas, $1,2-3,1 \times 0,2-0,7 \mathrm{~cm}$

1. H. brasiliense

11. Folhas coriáceas, $3,0-6,0 \times 0,7-1,0 \mathrm{~cm}$

11. H. rigidum

9. Folhas eretas, pouco ou nitidamente imbricadas

12. Folhas nitidamente imbricadas, 1,3-2,3 $\times 0,3-1,0 \mathrm{~cm}$; flor única terminal ou ramo florífero com ramificações laterais

8. H. microlicioides

12. Folhas às vezes imbricadas, $0,3-1,2 \times 0,1-0,7 \mathrm{~cm}$; inflorescências em cimas

dicotômicas terminais, 3-13 flora

7. H. denudatum

1. Hypericum brasiliense Choisy, Prodr. 1: 547. 1824. Tipo: Brasil, Rio de Janeiro, Gaudichaud 1, 1830, fl. fr. (Neótipo designado por Robson (1990) G, n.v.)

Fig. 1-9

Sinonímia: ver Rodríguez Jiménez (1980).

Erva anual ou subarbusto, 0,3-1,6 m alt., ereto; caule simples ou ramificado desde a base, marromavermelhado, córtex esfoliante, entrenós $0,2-5,0 \mathrm{~cm}$ compr.; folhas isomórficas, livres, perpendiculares ao caule, não imbricadas, 1,2-3,1×0,2-0,7 cm, elípticas, oblongas ou lanceoladas, ápice agudo, obtuso ou arredondado, base truncada, convexa ou arredondada, cartáceas, pouco pálidas na face abaxial, glândulas punctiformes visíveis na face abaxial, venação broquidódroma, margens planas ou revolutas, não colenquimatosas e escuras. Inflorescência em cimas dicotômicas terminais, geralmente com ramificações

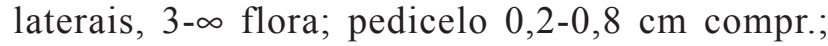
brácteas $0,2-0,5 \mathrm{~cm}$ compr., lineares ou lanceoladas, ápice agudo; flores 0,5-2,0 cm diâm.; sépalas $0,4-0,8 \times 0,1-0,3 \mathrm{~cm}$, iguais ou desiguais, imbricadas ou não, lineares, lanceoladas ou ovaladas, ápice agudo, glândulas punctiformes; pétalas $0,6-1,3 \times 0,2-0,6 \mathrm{~cm}$, obovadas ou oblongas, apículo agudo, amarelas ou alaranjadas, glândulas punctiformes; estames 45-80, 5-fasciculados, filetes $0,3-0,6 \mathrm{~cm}$ compr.; ovário 0,3-0,6 cm compr., ovóide ou elipsóide, pentacarpelar, estiletes 5, 0,2-0,3 cm compr., estigmas capitados. Cápsula 0,3-0,6 cm compr., ovóide ou cilíndrica, marrom, de comprimento maior, menor ou igual ao das sépalas. Sementes 0,5-1,0 $\mathrm{mm}$ compr., amarelas.
Material selecionado: BRASIL. Paraná: Campina Grande do Sul, 13/III/1990, fl. fr., Silva \& Cordeiro 829 (UPCB); Candói, 23/II/1996, fl. fr., Hatschbach et al. 6446 (EFC); Cascavel, 10/I/1953, fl. fr., $B$. Rambo 53586 (HBR); Curitiba, 28/XII/1957, fl. fr., Lange 1067 (UPCB, HBR); Guarapuava, 14/XII/1965, fl. fr., Reitz \& Klein 17612 (FLOR); Jaguariaíva, 24/X/1990, fl. fr., Cervi 3292 (UPCB); Lapa, 30/I/1949, fl., Hatschbach, 1185 (MBM); Londrina, 15/X/1986, fl., Vieira et al. 147 (FUEL); Ponta Grossa, 4/X/2001, fl. fr., Slusarski et al. 199 (UPCB); Porto Amazonas, 3/II/1976, fl., Kummrow 1063 (MBM); Quatro Barras, 6/IV/1990, fl. fr., Kunioyshi 55100 (EFC); São João do Triunfo, 13/XI/2001, fl. fr., Slusarski et al. 218 (UPCB).

Nomes populares: milfacadas, milfuradas, orelhade-gato, alecrim-bravo (Rodríguez Jiménez 1980), ervade-tigre, erva-de-bode (Paraná), erva-da-vida (Santa Catarina e Rio Grande do Sul).

Hypericum brasiliense apresenta distribuição nos Estados da Bahia, Paraná, Santa Catarina, Rio Grande do Sul, Rio de Janeiro, São Paulo e Minas Gerais. No Estado do Paraná, ocorre em todas as regiões fitogeográficas, como espécie heliófita de ambientes úmidos e secos, entre 500 a $1.200 \mathrm{~m}$ de altitude. Robson (1990) comentou que ocorrem variações nos espécimes encontrados da Bahia até Minas Gerais e Rio de Janeiro, comparados com os exemplares ocorrentes de São Paulo até o Rio Grande do Sul. Esta variação, decorrente da regionalidade, pode levar a indivíduos intermediários, porém não é adequado agrupá-los em táxons infra-específico. Diferencia-se 
166 Slusarski, Cervi \& Guimarães: Estudo taxonômico das espécies nativas de Hypericum L. (Hypericaceae)...

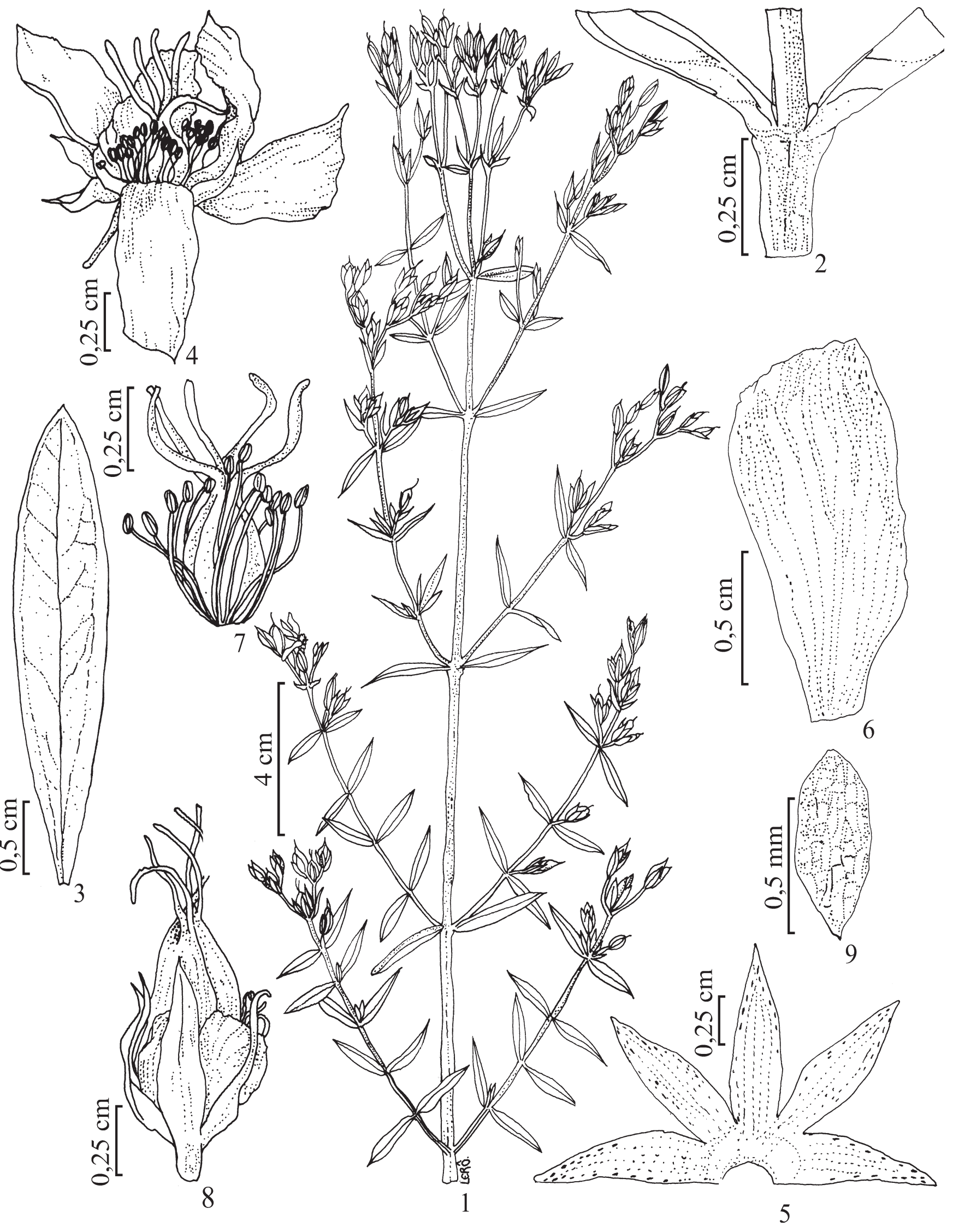

Figuras 1-9. Hypericum brasiliense Choisy. 1. Ramo florífero e frutífero. 2. Detalhe do caule com base das folhas. 3. Folha. 4. Flor. 5. Cálice. 6. Pétala. 7. Androceu e gineceu. 8. Cápsula. 9. Semente (Silva \& Cordeiro 829). 
de $H$. carinatum por apresentar folhas mais estreitas $(0,2-0,7 \mathrm{~cm})$, com a base truncada, convexa ou arredondada, enquanto $H$. carinatum apresenta folhas com 0,5-1,8 cm de largura e base decorrente e amplexicaule. Diferencia-se de $H$. denudatum por

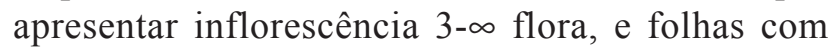
1,2-3,1 cm de comprimento, perpendiculares ao caule e não imbricadas, enquanto que $H$. denudatum apresenta inflorescência 3-7 flora, folhas com 0,3-1,2 $\mathrm{cm}$ de comprimento, eretas, às vezes imbricadas. Há dificuldades e divergências na separação de $H$. brasilense e $H$. campestre Cham. \& Schltdl. Segundo Robson (1990), a distinção entre as duas espécies é possível com a presença de frutos mais ou menos desenvolvidos, porém ainda assim é problemática. Entretanto, na análise dos espécimes do Estado do Paraná verificamos que as formas do ovário e cápsula, assim como o comprimento da cápsula em relação ao comprimento do cálice, podem variar no mesmo espécime. Devido a isto, todos os espécimes do Estado do Paraná, deste grupo, foram identificados como $H$. brasiliense. Assim, consideramos $H$. campestre sinônimo de $H$. brasiliense, concordando com Rodríguez Jiménez (1980). Floresce de outubro a março, e frutifica de outubro a abril.

2. Hypericum caprifoliatum Cham. \& Schltdl., Linnaea 3: 125. 1828.

Tipo: Brasil, São Paulo, Itararé, Sellow 1356, 1820, fl. (Holótipo B, destruído).

Fig. 10-15

Subarbusto 0,3-1,0 m alt., ereto; caule simples ou com ramificações laterais marrom-avermelhadas, córtex esfoliante, entrenós 1,0-2,5 cm compr.; folhas isomórficas, $2 / 3$ ou completamente conatas, perpendiculares ao caule, não imbricadas, 1,2-2,1×0,5-2,5 cm, ovalado-deltóides ou oblongas, ápice agudo ou obtuso, base não decorrente, cartáceas, pouco pálidas na face abaxial, glândulas punctiformes visíveis na face abaxial, venação broquidódroma, margens planas ou revolutas, não colenquimatosas e escuras. Inflorescência em cimas dicotômicas terminais, geralmente com ramificações laterais, 3-19-flora; pedicelo 0,2-0,5 cm compr.; brácteas 0,1-0,4 cm compr., triangulares, ápice agudo; flores 1,3-2,0 cm diâm.; sépalas 0,8-1,0× 0,3-0,4 cm, desiguais, imbricadas, oblongas, elípticas ou lanceoladas, ápice agudo ou obtuso, glândulas punctiformes; pétalas 1,2-1,8×0,3-0,6 cm, obovadas ou oblongo-lanceoladas, apículo subagudo, amarelas ou alaranjadas, glândulas punctiformes; estames $50-\infty$, irregularmente fasciculados, filetes $0,7-1,0 \mathrm{~cm}$ compr.; ovário 0,4-0,6 cm compr., elipsóide, pentacarpelar, estiletes 5, 0,5-0,7 cm compr., estigmas capitados. Cápsula 0,8-1,0 cm compr., globosa, marrom, de comprimento subigual ao das sépalas. Sementes 0,5-0,8 mm compr., amarelas.

Material selecionado: BRASIL. Paraná: Clevelândia, 28/X/1956, fl. fr., Hatschbach 6999 (MBM); Jaguariaíva, 8/II/2002, fl. fr., Slusarski et al. 225 (UPCB); Piraquara, 30/VI/1993, fl., Bufrem \& Ziller 28 (EFC); Quitandinha, 5/XI/1964, fl. fr., Mattos 12320 (SP).

Nomes populares: orelha-de-gato (Rodríguez Jiménez 1980) e escadinha (Rio Grande do Sul).

Segundo Robson (1990), ocorre no sul do Brasil e na Argentina (Misiones). No Estado do Paraná, ocorre na FOM, Estepe Gramíneo-Lenhosa e Savana Arbustiva. Espécie heliófita, de ambientes secos ou úmidos, entre 10 a $1.300 \mathrm{~m}$ de altitude. Hypericum caprifoliatum é semelhante a $H$. connatum, diferenciando-se desta por apresentar caule simples ou com ramificações laterais, folhas ovalado-deltóides ou oblongas, cartáceas, sem margens colenquimatosas escuras, $2 / 3$ ou completamente conatas, estames irregularmente fasciculados, e pétalas com apículo terminal subagudo. Hypericum connatum possui caule simples, raramente ramificado desde a base, folhas ovalado-deltóides ou semi-circulares, completamente conatas, coriáceas, margens colenquimatosas e escuras, estames 5-fasciculados e pétalas sem apículo terminal. Floresce de setembro a maio, e frutifica de outubro a junho.

3. Hypericum carinatum Griseb., Symb. Fl. Arg.: 41. 1879.

Tipo: Argentina, Córdoba, Sierra Achala, Hieronymus 881, fevereiro 1877, fl. (Holótipo GOET, n.v.).

Sinonímia: ver Robson (1990).

Fig. 16-22

Erva anual ou subarbusto $0,5-0,8 \mathrm{~m}$ alt., ereto; caule simples ou ramificado desde a base, verde ou marrom-avermelhado, córtex persistente, entrenós 1,2-4,3 cm compr.; folhas isomórficas, livres, suberetas, não imbricadas, $1,7-5,3 \times 0,5-1,8 \mathrm{~cm}$, oblongas, elípticooblongas, ovalado-lanceoladas ou oblongo-lanceoladas, ápice agudo ou arredondado, base decorrente e amplexicaule, cartáceas, pouco pálidas na face abaxial, glândulas punctiformes visíveis na face abaxial, venação broquidódroma, margens planas ou revolutas, não colenquimatosas e escuras. Inflorescência em cimas dicotômicas terminais, com ramificações laterais, 7-12(-20)-flora; pedicelo 0,2-0,6 cm compr.; brácteas 


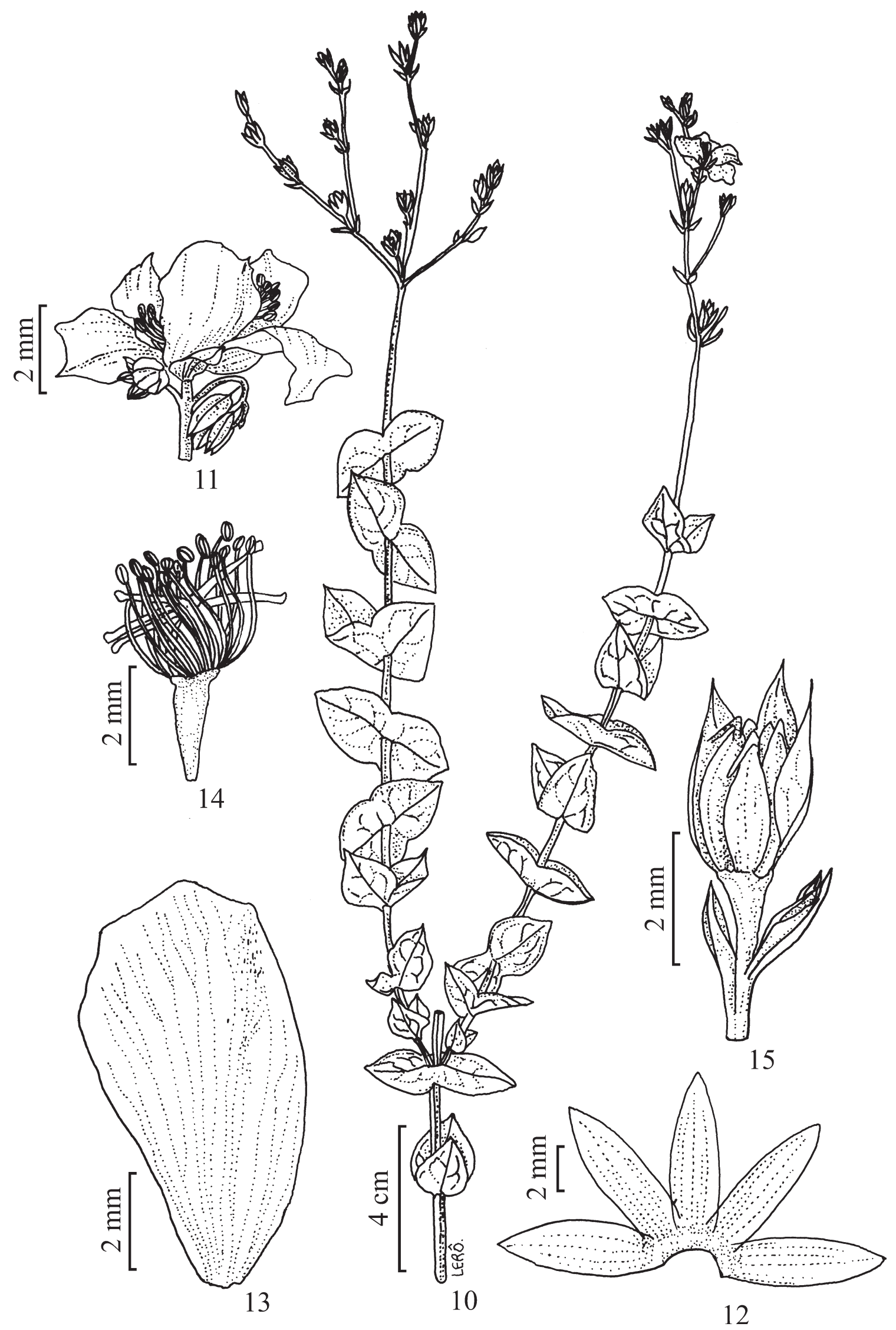

Figuras 10-15. Hypericum caprifoliatum Cham. \& Schltdl. 10. Ramo florífero e frutífero. 11. Flor. 12. Cálice. 13. Pétala. 14. Androceu e gineceu. 15. Cápsula jovem (Slusarski et al. 225). 


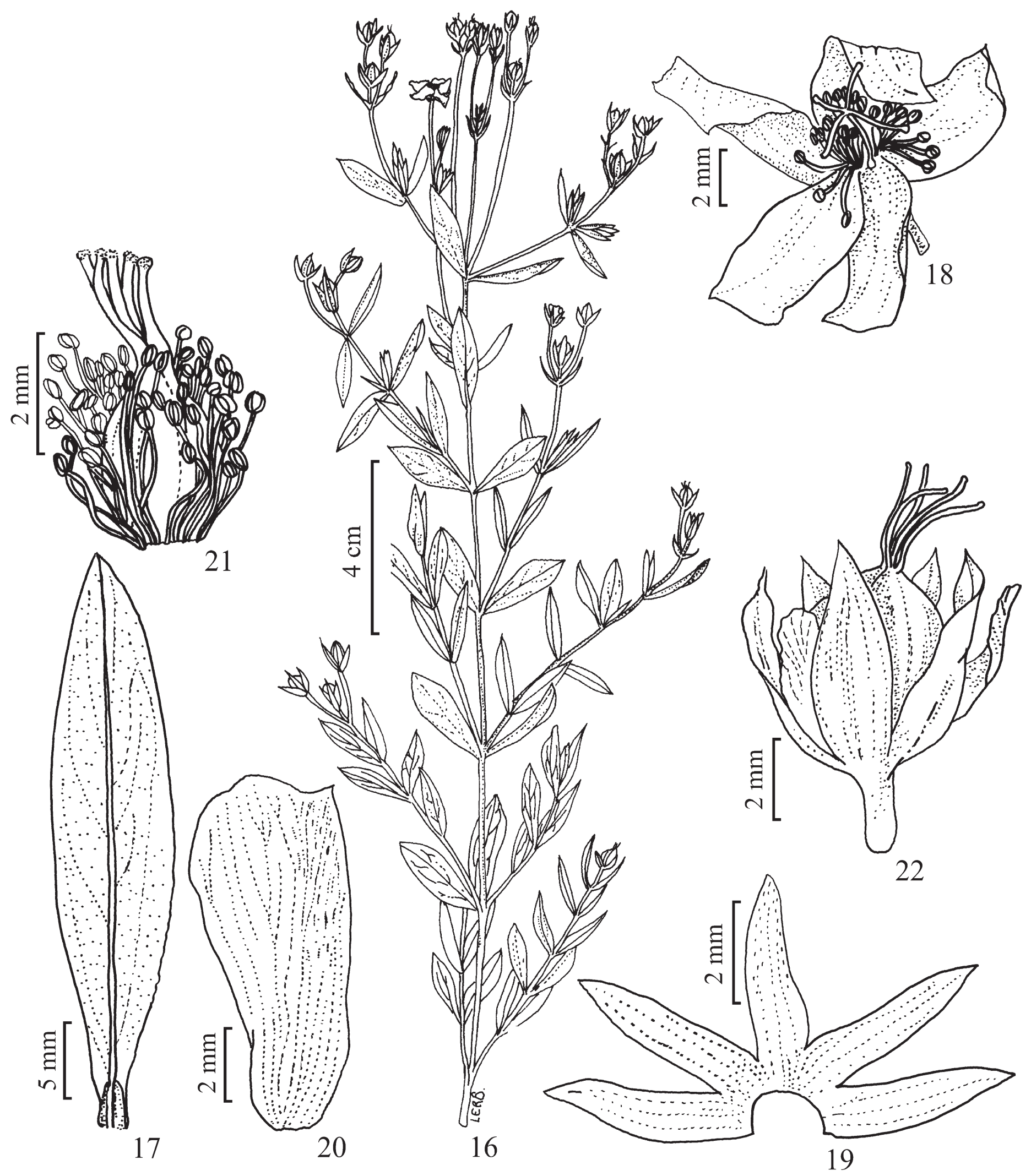

Figuras 16-22. Hypericum carinatum Griseb. 16. Ramo florífero e frutífero. 17. Folha. 18. Flor. 19. Cálice. 20. Pétala. 21. Androceu e gineceu. 22. Cápsula em formação (Hatschbach 21020). 
0,4-0,7 cm compr., lineares, lanceoladas ou oblongas, ápice agudo; flores 1,2-2,4 cm diâm.; sépalas $0,5-1,4 \times 0,2-0,4 \mathrm{~cm}$, iguais, imbricadas, lineares ou lanceoladas, ápice agudo ou acuminado, glândulas lineares; pétalas 1,2-2,5×0,5-0,7 cm, obovadas ou oblongo-lanceoladas, apículo agudo, amarelas ou alaranjadas, glândulas lineares; estames 64- $\infty$, 5-fasciculados, filetes $0,6-1,0 \mathrm{~cm}$ compr.; ovário 0,4-0,7 cm compr., ovóide, pentacarpelar, estiletes 5, 0,3-0,6 cm compr., estigmas clavados. Cápsula 0,6-1,0 cm compr., ovóide ou globosa, marrom, de comprimento subigual ao das sépalas. Sementes 0,7-1,3 mm compr., amarelas.

Material selecionado: BRASIL. Paraná: Guarapuava, 7/II/1969, fl. fr., Hatschbach 21020 (MBM, RFA, UPCB); Mariópolis, 26/II/1982, fl. fr., Kummrow \& Stutts 1824 (MBM).

Segundo Robson (1990), esta espécie distribui-se no sul do Brasil, Paraguai, Argentina e Uruguai. No Estado do Paraná, ocorre na FOM e na Estepe Gramíneo-Lenhosa, entre 650 e $1.200 \mathrm{~m}$ de altitude. Espécie heliófita, de ambientes úmidos e ruderais. Hypericum carinatum é uma espécie de fácil identificação, com folhas de formas variadas e com base marcadamente decorrente e amplexicaule. Hatschbach \& Ziller (1995) relataram que H. carinatum é uma espécie rara no Estado do Paraná, o que foi confirmado neste trabalho, onde foram encontrados apenas quatro exemplares coletados para o Estado. Floresce e frutifica de novembro a maio.

4. Hypericum connatum Lam., Encycl. 4: 168. 1797. Tipo: Montevideo, Uruguai, Commerson s.n., maio 1767, fl. fr. (Holótipo P, n.v.).

Sinonímia: ver Robson (1990).

Fig. 23-28

Erva perene ou subarbusto 0,3-0,8 m alt., ereto; caule simples, raramente ramificado desde a base, marrom-avermelhado, córtex esfoliante, entrenós 1,7-6,0 cm compr.; folhas isomórficas, completamente conatas, perpendiculares ao caule, não imbricadas, 1,1-2,5×1,0-3,5 cm, ovalado-deltóides ou semicirculares, ápice agudo ou arredondado, base conata, coriáceas, pouco pálidas na face abaxial, glândulas punctiformes visíveis em ambas as faces, porém mais evidentes na face abaxial, venação broquidódroma, margens revolutas, colenquimatosas e escuras. Inflorescência em cimas dicotômicas terminais, sem

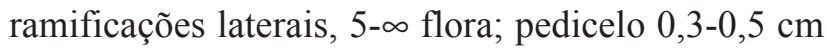
compr.; brácteas 0,2-0,4 cm compr., linear-lanceoladas, ápice agudo; flores 2,0-3,0 cm diâm.; sépalas
$0,6-0,8 \times 0,2-0,4 \mathrm{~cm}$, desiguais, imbricadas, ovaladas ou elípticas, ápice agudo ou acuminado, glândulas lineares e punctiformes; pétalas 1,0-2,1×0,4-0,7 cm, oblongolanceoladas ou obovadas, apículo ausente, amarelas ou alaranjadas, glândulas lineares; estames $50-\infty$, 5-fasciculados, filetes $0,2-0,4 \mathrm{~cm}$ compr.; ovário 0,3-0,5 cm compr., ovóide, pentacarpelar, estiletes (4-)5, 0,2-0,6 cm compr., estigmas capitados ou clavados. Cápsula 0,4-0,6 cm compr., ovóide, marrom, de comprimento subigual ao das sépalas. Sementes 0,7-0,9 mm compr., amarelas.

Material selecionado: BRASIL. Paraná: Curitiba, 25/X/2001, fl. fr., Slusarski \& Cervi 201 (UPCB); Guarapuava, 15/IX/1988, fl., Hatschbach \& Silva 52304 (MBM); Jaguariaíva, 16/II/1982, fl. fr., Kummrow \& Stutts 1761 (MBM); Lapa, 30/I/1949, fl. fr., Hatschbach 1184 (MBM); Laranjeiras do Sul, 10/XII/1968, fl. fr., Hatschbach 20606 (MBM); Palmas, 3/XII/1071, fl. fr., Hatschbach 28146 (MBM);

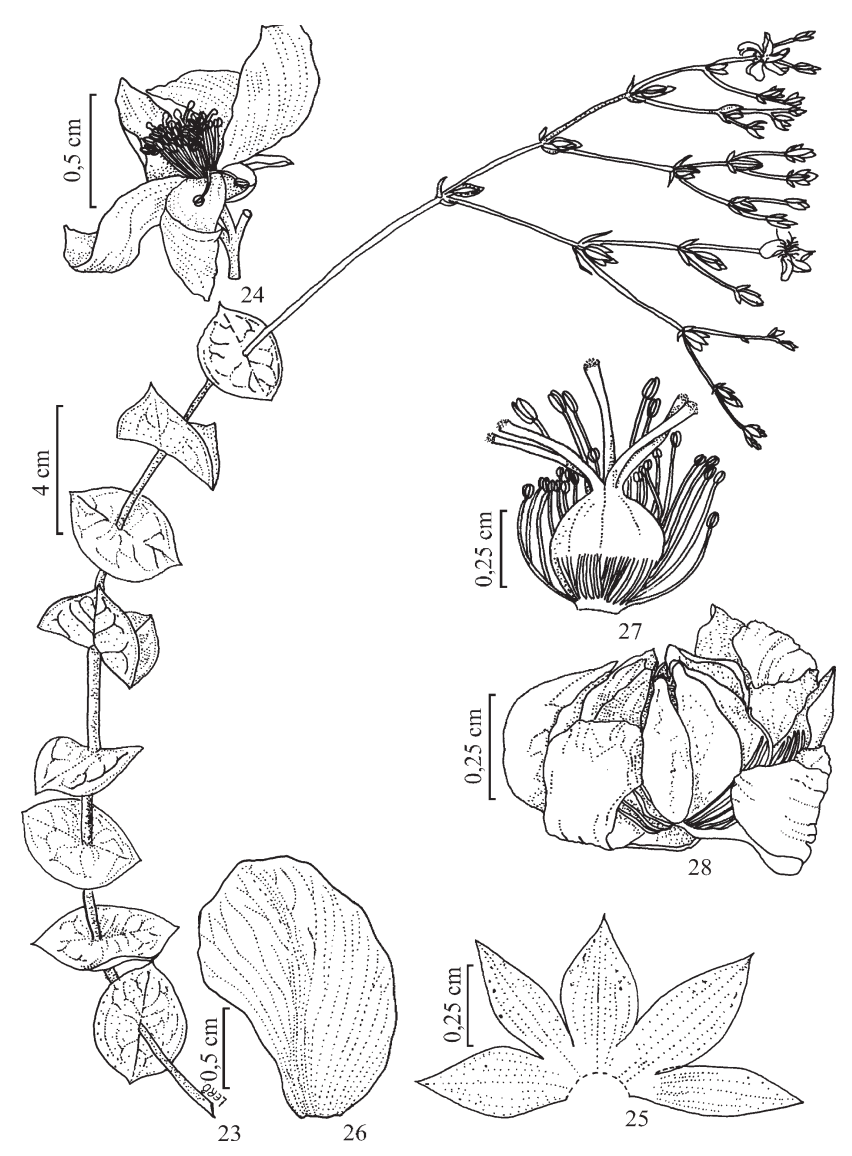

Figuras 23-28. Hypericum connatum Lam. 23. Ramo florífero e frutífero. 24. Flor. 25. Cálice. 26. Pétala. 27. Androceu, estames em parte removidos, e gineceu. 28. Cápsula envolta pela flor (Slusarski et al. 222). 
Palmeira, Recanto dos Papagaios, 15/X/2001, fr., Slusarski et al. 222 (UPCB). Porto Amazonas, 17/XII/1929, fl., Gurgel 59 (RB); Rio Branco do Sul, 26/I/1961, fl. fr., Hatschbach 7835 (MBM); Rio Negro,19/II/1988, fl. fr., Hatschbach \& Ribas 51887 (MBM); Tibagi, 2/XI/1964, fl. fr., Hatschbach 11821 (MBM).

Nomes populares: orelha-de-gato (Paraná e Rio Grande do Sul, Saint-Hilaire et al. 1824; Reichardt 1878; Caminhoá 1884; Corrêa 1909; Rodríguez Jiménez 1980) e orelha-de-rato (Paraná). Na Argentina, além de orelha-de-gato, também é conhecida por "sombrerito" (Ceballos 1995).

Hypericum connatum apresenta distribuição nos Estados do Paraná, Santa Catarina, Rio Grande do Sul, São Paulo e Rio de Janeiro. No Estado do Paraná, ocorre na FOM, FOD, Estepe Gramíneo-Lenhosa e Savana Arbustiva. Espécie heliófita, sub-xerófita, pouco freqüente em solos úmidos, ocorre entre 700 e $1.350 \mathrm{~m}$ de altitude. É facilmente reconhecida pela particularidade de suas folhas ovalado-deltóides ou semicirculares, coriáceas, completamente conatas, margens revolutas, colenquimatosas e escuras. Floresce de setembro a junho, e frutifica de outubro a agosto.

5. Hypericum cordatum (Vell.) N. Robson subsp. cordatum, Bull. Br. Mus. Hist. (Bot) 20 (1): 59. 1990. Tipo: Brasil, São Paulo, próximo à zona urbana de São Paulo, Saint Hilaire 1172, 1819, fl. (Holótipo e isótipo P, n.v.).

Sinonímia: ver Robson (1990).

Fig. 29-35

Erva perene, com base lignificada, ou subarbusto 0,2-0,6 m alt., ereto ou decumbente; caule ramificado desde a base ou acima desta, marrom-avermelhado, córtex esfoliante, entrenós $0,5-2,2 \mathrm{~cm}$ compr.; folhas isomórficas, livres ou $1 / 3$ conatas, eretas, pouco imbricadas, $0,6-1,7 \times 0,2-0,8 \mathrm{~cm}$, largamente ovaladas, ovalado-triangulares ou ovalado-oblongas, ápice agudo ou obtuso, base cordada, coriáceas, pouco pálidas ou esverdeadas na face abaxial, glândulas punctiformes visíveis na face abaxial, venação hifódroma, margens planas ou revolutas, colenquimatosas ou não. Inflorescência em cimas dicotômicas terminais, às vezes com ramificações laterais, 3-25 flora; pedicelo 0,1-0,3 cm compr.; brácteas $0,4-0,7 \mathrm{~cm}$ compr., lanceoladas, ápice agudo; flores 0,5-3,0 cm diâm.; sépalas $0,8-1,3 \times 0,4-0,7 \mathrm{~cm}$, desiguais, imbricadas, ovaladas ou lanceoladas, ápice agudo ou obtuso, glândulas lineares e punctiformes; pétalas $0,8-1,6 \times$ 0,4-0,8 cm, obovadas ou oblongas, apículo agudo, amarelas ou alaranjadas, glândulas lineares; estames 48- $\infty$, 3-4-fasciculados, filetes $0,4-0,8 \mathrm{~cm}$ compr.; ovário 0,2-0,6 cm compr., ovóide ou subgloboso, tricarpelar, estiletes $3(-4), 0,4-0,8 \mathrm{~cm}$ compr., estigmas capitados. Cápsula 0,5-0,9 cm compr., ovóide-subglobosa, marrom, de comprimento subigual ao das sépalas. Sementes 0,8-1,0 mm compr., amarelas.

Material selecionado: BRASIL. Paraná: Guarapuava, 14/II/1949, fr., Brade 19640 (RB); Jaguariaíva, 17/XII/1991, fl., Cervi et al. 3504 (UPCB); Lapa, 30/I/1949, fl. fr., Hatschbach 1182 (MBM); Palmeira, 5/XII/2001, fl., Slusarski et al. 221 (UPCB); Piraquara, 2/II/1972, fl. fr., Imaguire 2826 (MBM); Ponta Grossa, 13/I/1964, fr., Pereira 8258 (RB); Idem, Passo do Pupo, 10/X/1967, fl., Hatschbach 17386 (MBM); São José dos Pinhais, 30/IX/1988, fl., Chules 8 (HUCP).

Nomes populares: orelha-de-gato (Paraná, Rodríguez Jiménez 1980).

Distribui-se nos Estados do Paraná, Santa Catarina, Rio Grande do Sul e São Paulo. No Estado do Paraná, ocorre na FOM, Estepe Gramíneo-Lenhosa e Savana Arbustiva. Hypericum cordatum subsp. cordatum é heliófita e indiferente quanto às condições físicas do solo, ocorrendo em ambientes úmidos ou secos. Caracteriza-se por suas folhas largamente ovaladas, ovalado-triangulares ou ovalado-oblongas, de base cordiforme, flores com 0,5-3,0 cm de diâmetro. Hypericum cordatum subsp. kleinii N. Robson diferencia-se pelas folhas elípticas, oblongas ou triangular-lanceoladas, com margens inteiras e base subcordada, e flores de 0,5-1,5 cm de diâmetro. Floresce e frutifica praticamente o ano todo.

6. Hypericum cordatum subsp. kleinii N. Robson, Bull. Br. Mus. Nat. Hist. (Bot) 20(1): 60. 1990.

Tipo: Brasil, Santa Catarina, entre Palmeiras e Lajes, 800-900m, Smith \& Klein 8100, dezembro 1956 (fl.) (Holótipo US; isótipo NY, n.v.).

Fig. 36-37

Material selecionado: BRASIL. Paraná: Curitiba, 12/X/1984, fl., Trefflih 25 (HUCP); Guarapuava, 16/II/1949, fr., Brade 19645 (RB); Palmas, 4/XII/1971, fl., Hatschbach et al. 28161 (MBM); Ponta Grossa, 18/X/1989, fl. fr., Cervi et al. 2861 (UPCB).

Nomes populares: milfacadas (Paraná), alecrimbravo (Paraná) e orelha-de-gato (Rodríguez Jiménez 1980).

Hypericum cordatum subsp. kleinii apresenta distribuição nos Estados do Paraná, Santa Catarina, 
São Paulo e Minas Gerais. No Estado do Paraná, ocorre na FOM e Estepe Gramíneo-Lenhosa. Espécie heliófita e seletiva sub-xerófita de campos limpos, secos e pedregosos. Esta subespécie é semelhante a H. ternum diferenciando-se desta por possuir folhas isomórficas, inflorescência em cimas terminais com ramos muito folhosos e flores com $0,5-1,5 \mathrm{~cm}$ de diâmetro. Hypericum ternum apresenta folhas isomórficas, todas estreitas, ou heteromórficas, inflorescência em cimas terminais alongadas com ramos pouco folhosos, e flores com $0,8-1,0 \mathrm{~cm}$ de diâmetro. Floresce e frutifica de outubro a maio.

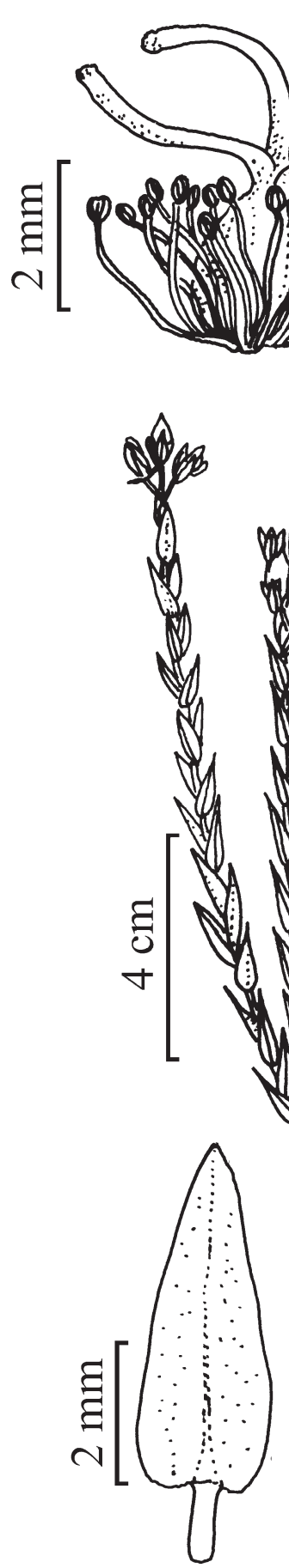

37

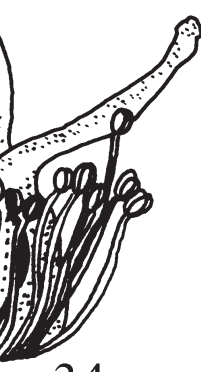

34
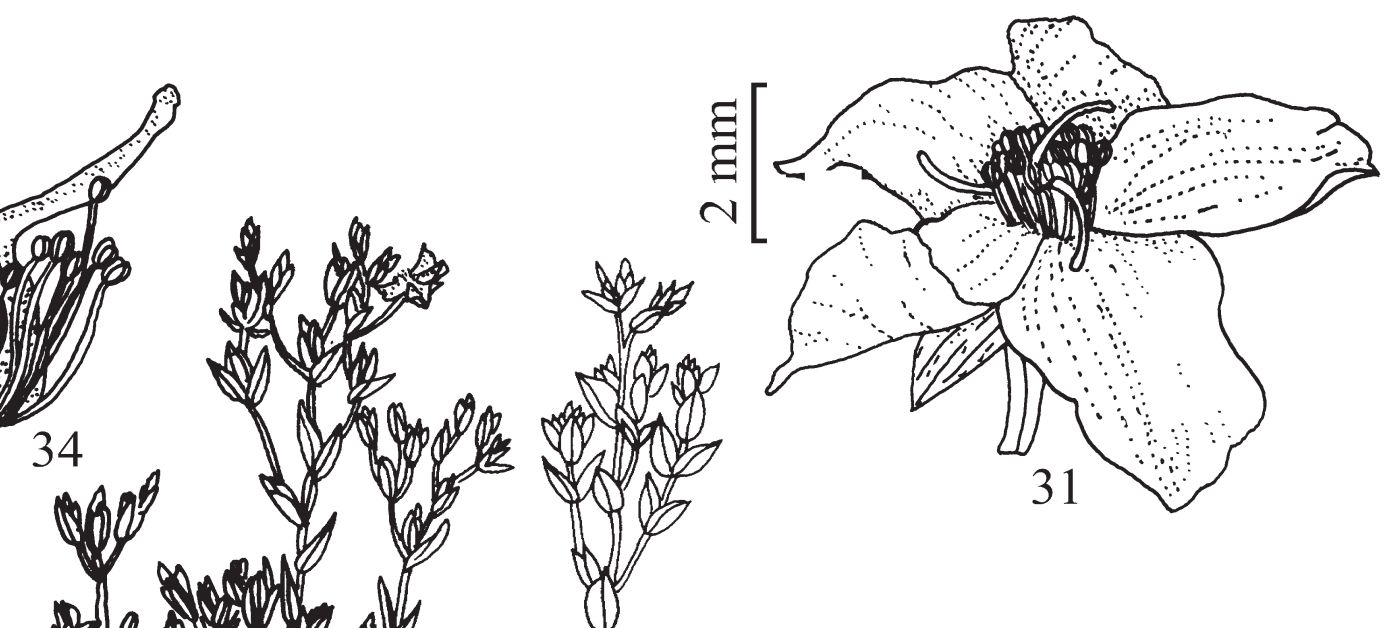

Figuras 29-35. Hypericum cordatum (Vell.) N. Robson subsp. cordatum. 29. Ramo florífero e frutífero. 30. Folha. 31. Flor. 32. Cálice. 33. Pétala. 34. Androceu e gineceu. 35. Cápsula em formação (Hatschbach 17386). 36-37. Hypericum cordatum subsp. kleinii N. Robson. 36. Ramo florífero. 37. Folha (Hatschbach et al. 28161). 
7. Hypericum denudatum A. St.-Hil., Fl. Bras. Mer. 1:336. 1828.

Tipo: Brasil, Paraná, margens do Yapo, próximo à Barro do Yapo, Saint Hilaire 1530, fevereiro 1816-1821, fl. (Holótipo P, n.v.).

Sinonimia: ver Robson (1990).

\section{Fig. 38-45}

Subarbusto ou arbusto $0,2-1,5 \mathrm{~m}$ alt., ereto ou decumbente; caule ramificado desde a base, marrom, córtex esfoliante, entrenós $0,3-0,5 \mathrm{~cm}$ compr.; folhas isomórficas, livres, eretas, às vezes imbricadas, 0,3-1,2×0,1-0,7 cm, elíptico-oblongas ou lineares, ápice agudo, obtuso ou arredondado, base convexa, subcoriáceas, ambas as faces de mesma coloração, glândulas punctiformes visíveis na face abaxial, venação eucamptódroma, margens planas ou revolutas, não colenquimatosas e escuras. Inflorescência em cimas dicotômicas terminais, com ramificações laterais, 3-7-flora; pedicelo $0,1-0,3 \mathrm{~cm}$ compr.; brácteas $0,2-0,4 \mathrm{~cm}$ compr., lineares ou lanceoladas, ápice agudo; flores 1,0-1,8 cm diâm.; sépalas $0,6-0,8 \times 0,2-0,3 \mathrm{~cm}$, iguais, não imbricadas, linear-lanceoladas, ápice agudo, glândulas lineares e punctiformes; pétalas $0,4-0,8 \times 0,2-0,5 \mathrm{~cm}$, oblanceoladas, apículo agudo, amarelas, glândulas lineares e punctiformes; estames 44-52, 5-fasciculados, filetes 0,6-0,7 cm compr.; ovário 0,4-0,7 cm compr., elipsóide, tri ou pentacarpelar, estiletes 5, 0,4-0,6 cm compr., estigmas capitados. Cápsula 1,0-1,2 cm compr., oblonga, marrom, de comprimento maior ao das sépalas. Sementes 1,0-1,2 mm compr., amarelas.

Material selecionado: BRASIL. Paraná: Adrianópolis, 21/II/1978, fl. fr., Lourteig \& Hatschbach 3178 (MBM); Curitiba, 23/XI/1970, fl. fr., Hatschbach 25605 (UPCB); General Carneiro, 12/II/1966, fl. fr., Hatschbach et al.13732 (MBM); Piraí do Sul, Tijuco Preto, 17/XI/1970, fl. Fr., Hatschbach \& Guimarães 25420 (MBM); São Mateus do Sul, 30/X/1985, fl. fr., Britez 190 (UPCB); Tijucas do Sul, 7/IV/1958, fl. fr., Hatschbach 4519 (HBR, MBM, UPCB); União da Vitória, 18/XI/1972, fl. fr., Hatschbach 30090 (MBM).

Nomes populares: milfacadas, milfuradas, orelhade-gato e alecrim-bravo (Rodríguez Jiménez 1980).

Hypericum denudatum apresenta distribuição nos Estados do sul do Brasil. No Estado do Paraná, ocorre na FOM e Estepe Gramíneo-Lenhosa. Espécie heliófita, seletiva higrófita e ruderal, entre 250 e $1.200 \mathrm{~m}$ de altitude. Esta espécie é semelhante a $H$. brasiliense, diferenciando-se desta por apresentar folhas com $0,3-1,2 \times 0,1-0,7 \mathrm{~cm}$, subcoriáceas, às vezes imbricadas, inflorescência 3-7-flora e estames variando em número de 44-52. Hypericum brasiliense possui folhas com 1,2-3,1×0,2-0,7 cm, cartáceas e perpendiculares aos ramos, não imbricadas, inflorescência $3-\infty$ flora e estames variando de 45-80. Floresce de outubro a abril, e frutifica de dezembro a maio.

8. Hypericum microlicioides L.B. Sm., J. Wash. Acad. Sci. 48: 311, f.1, g-i, 1958.

Tipo: Brasil, Santa Catarina, Campo Alegre, Morro do Iquererim, Smith \& Klein 8535, dezembro 1956, fl. (Holótipo US; isótipos P, NY, n.v., HBR!).

Fig. 46-53

Erva perene, com base lignificada, ou subarbusto 0,2-0,7 $\mathrm{m}$ alt., decumbente; caule ramificado desde a base, pardo, córtex esfoliante; entrenós $0,4-1,0 \mathrm{~cm}$ compr.; folhas isomórficas, livres, eretas, nitidamente imbricadas, 1,3-2,3×0,3-1,0 cm, elípticas, oblongas ou lanceoladas, ápice agudo, base convexa, subcoriáceas, pouco pálidas na face abaxial, glândulas punctiformes laminares, venação broquidódroma, margens planas ou revolutas, não colenquimatosas e escuras. Inflorescência com 1 flor terminal, ou ramo florífero com ramificações laterais; pedicelo 0,2-0,5 cm compr.; brácteas $0,1-0,2 \times 0,5-0,7 \mathrm{~cm}$, lanceoladas, ápice agudo; flores 1,5-2,5 cm diâm.; sépalas 0,1-1,7×0,3-0,5 cm, iguais, não imbricadas, lanceoladas, ápice agudo, glândulas punctiformes; pétalas 1,3-1,5×0,3-0,5 cm, obovadas, apículo subagudo, amarelas, glândulas lineares; estames $80-\infty, 5$-fasciculados, filetes 0,4-0,6 cm compr.; ovário 0,5-0,7 cm compr., ovóide, pentacarpelar, estiletes 5, 0,1-0,3 cm compr., estigmas clavados. cápsula $0,5 \mathrm{~cm}$ compr., elipsóide, marrom, de comprimento maior ao das sépalas. Sementes não vistas.

Material selecionado: BRASIL. Paraná. Curitiba, Atuba, 16/XII/1960, fl., Hatschbach 7468 (MBM); Guaratuba, Serra do Araçatuba, Morro dos Perdidos, 19/XI/1971, fl. fr., Hatschbach 28096 (MBM), Idem, 24/X/2001, fl., Slusarski \& Santos 200 (UPCB); idem, 23/XI/1996, fl., Santos et al. 292 (MBM).

Hypericum microlicioides apresenta distribuição restrita aos Estados do Paraná e Santa Catarina.

Apesar de não haver citação para o Estado do Rio Grande do Sul, é provável que a espécie também ocorra neste Estado, em condições ambientais são similares. No Estado do Paraná, ocorre na FOD e FOM, entre 900 e $1.500 \mathrm{~m}$ de altitude. Espécie heliófita, de ambientes úmidos ou inundados e pedregosos de encostas graminosas. Diferencia-se de $H$. rigidum por apresentar folhas subcoriáceas, eretas, nitidamente 

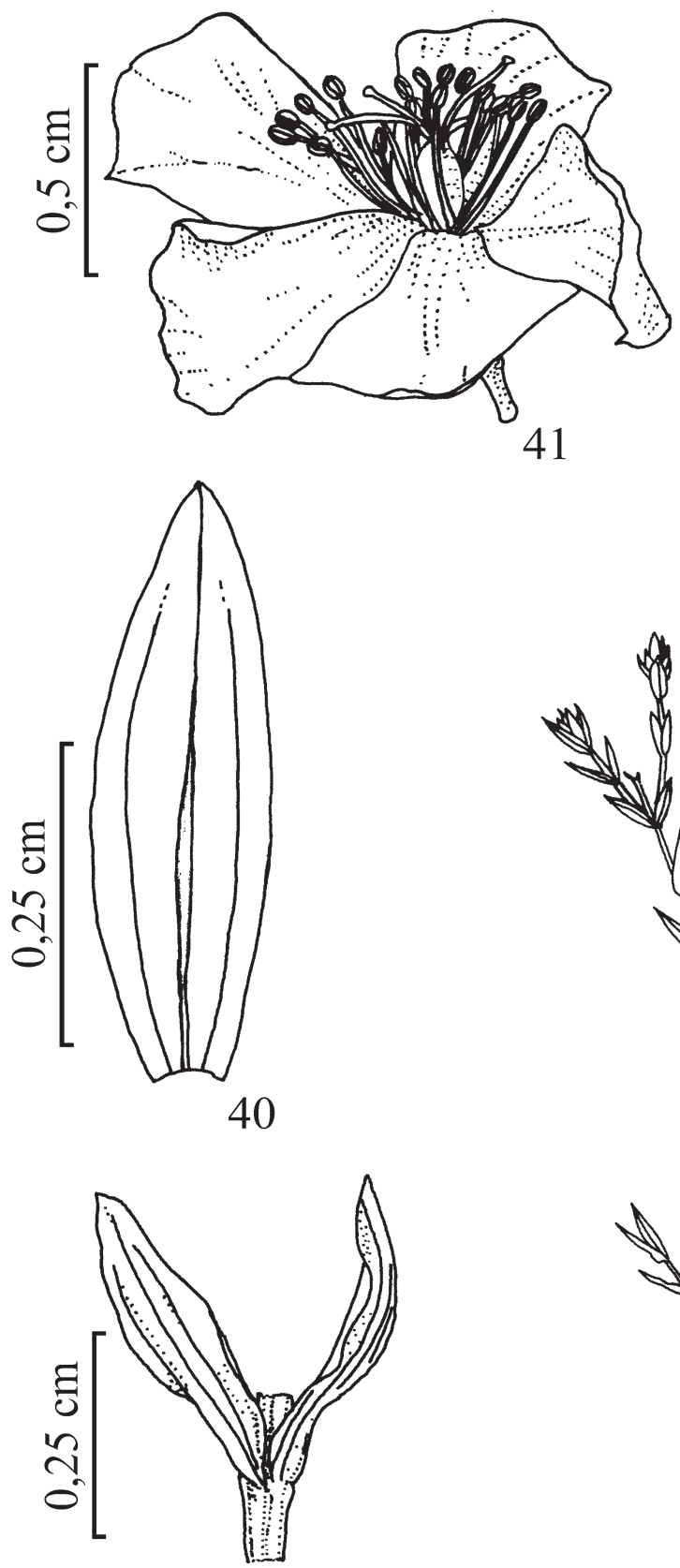

39

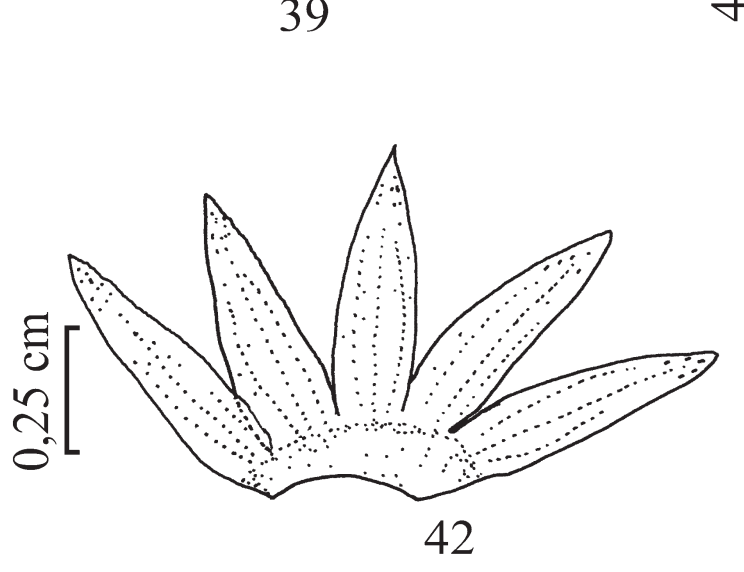
38

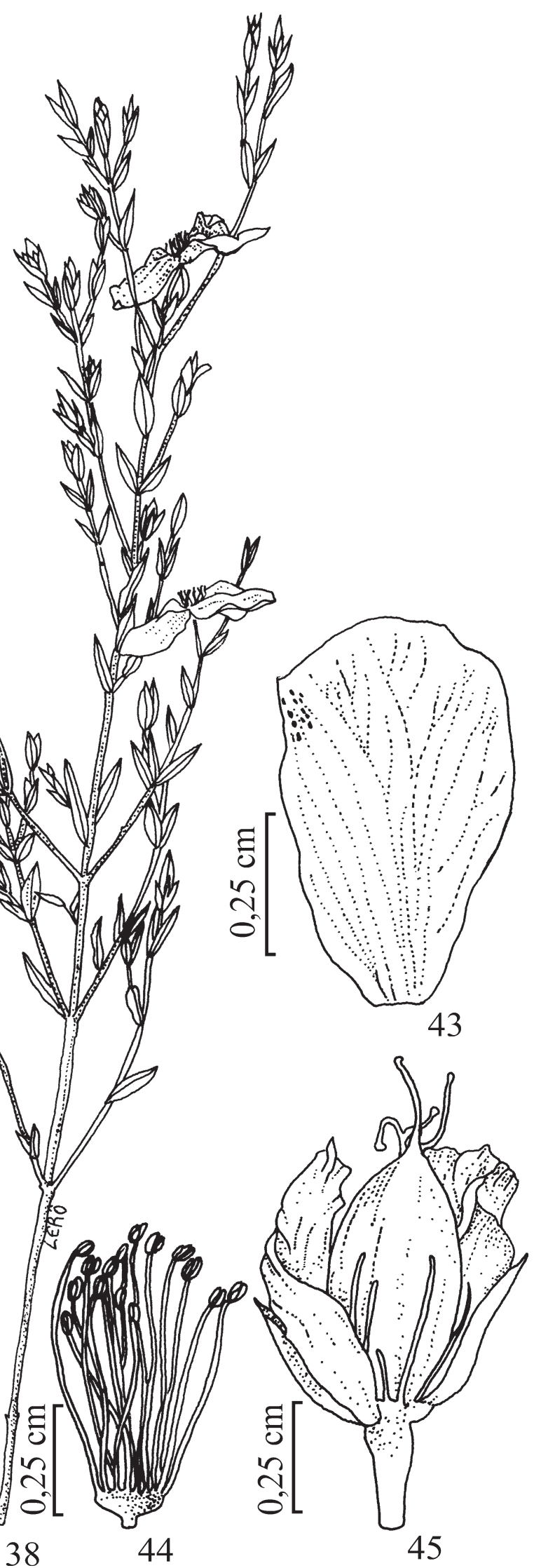

Figuras 38-45. Hypericum denudatum A. St.-Hil. 38. Ramo florífero e frutífero. 39. Detalhe do caule com folhas. 40. Folha. 41. Flor. 42. Cálice. 43. Pétala. 44. Androceu. 45. Cápsula (Hatschbach \& Guimarães 25420). 

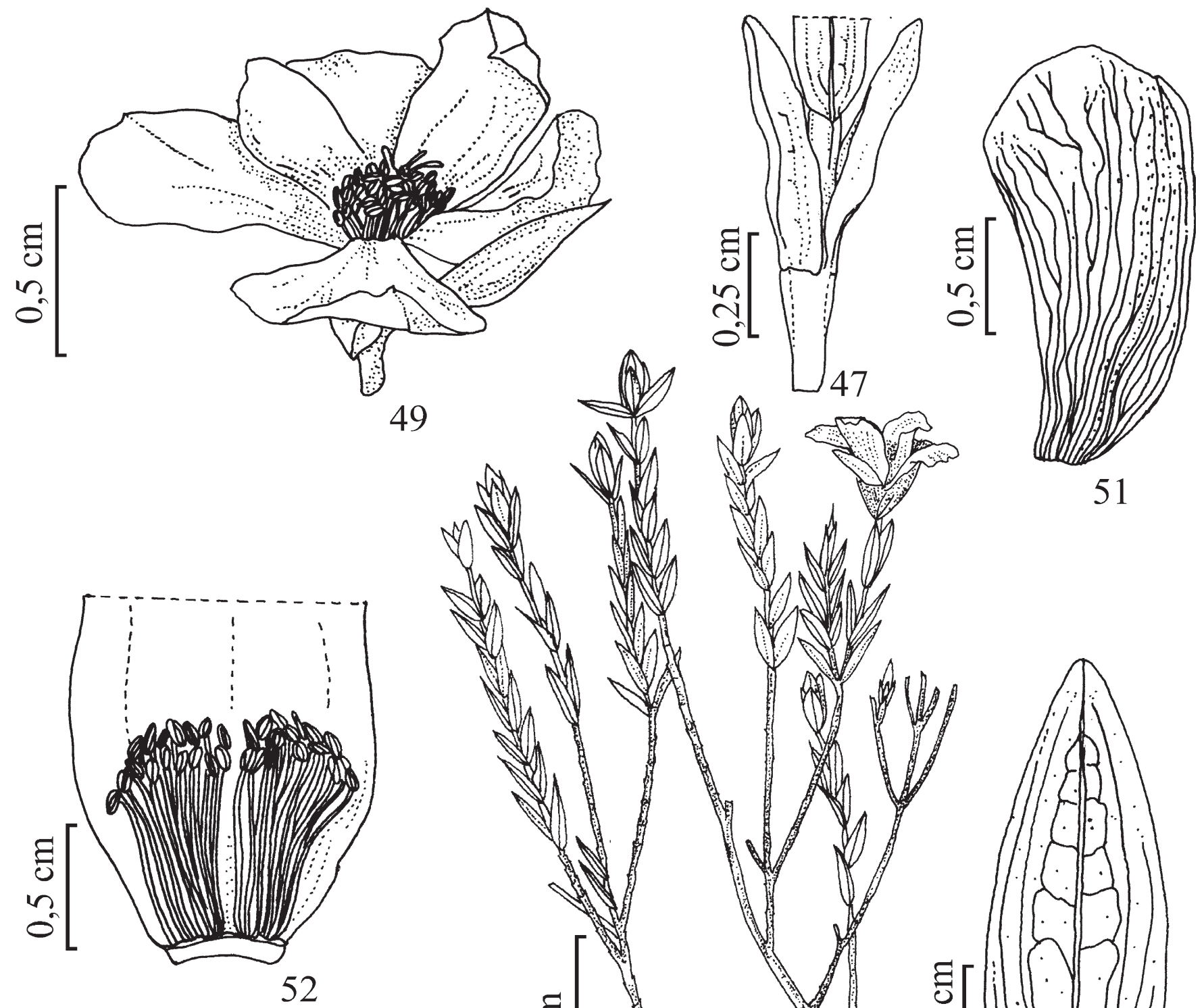

49

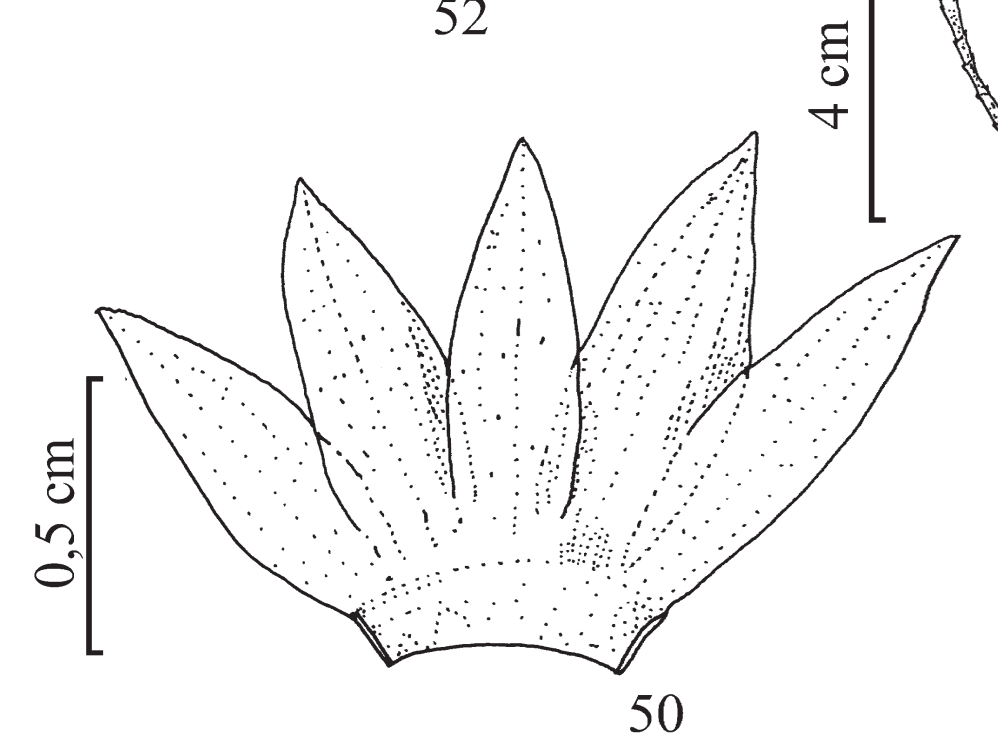

Figuras 46-53. Hypericum microlicioides L.B. Sm. 46. Ramo florífero e frutífero. 47. Detalhe do caule com folhas. 48. Folha. 49. Flor. 50. Cálice. 51. Pétala. 52. Androceu. 53. Cápsula (Santos et al. 292). 
imbricadas, 1,3-2,3×0,3-1,0 cm, flor única terminal ou ramos floríferos com ramificações laterais, flores 1,5-2,5 cm de diâmetro, enquanto $H$. rigidum possui folhas coriáceas, perpendiculares aos ramos, não imbricadas, 3,0-6,0×0,7-1,0 cm, inflorescência em cimas terminais, 3-5-flora, flores $0,7-1,3 \mathrm{~cm}$ diâmetro. Floresce de novembro a abril, e frutifica em novembro.

9. Hypericum mutilum L. subsp. mutilum, Sp. pl.: 787. 1753.

Tipo: Canadá, Virginia, Clayton 232, s.d. (Lectótipo designado por Robson 1980, BM, n.v.).

Sinonímia: ver Robson (1990).

Fig. 54-60

Erva anual ou perene, 0,8-0,15 m alt., ereta ou decumbente; caule simples ou ramificado desde a base, verde ou marrom, córtex persistente, entrenós 0,9-2,0 cm compr.; folhas isomórficas, livres, perpendiculares ao caule, não imbricadas, 0,9-1,4× 0,6-1,0 cm, ovaladas ou suborbiculares, ápice obtuso ou arredondado, base arredondada ou convexa, membranáceas, concolores, glândulas punctiformes em ambas as faces, venação broquidódroma, margens planas, não colenquimatosas e escuras. Inflorescência em cimas dicotômicas terminais, geralmente com ramificações laterais, 5- $\infty$ flora; pedicelo $0,5-1,0 \mathrm{~cm}$ compr.; brácteas 0,2-0,3 cm compr., lanceoladas, ápice agudo; flores 0,3-0,5 cm diâm.; sépalas 3,1-6,5× $1,0-1,5 \mathrm{~cm}$, iguais ou desiguais, imbricadas ou não, lineares, lanceoladas, elípticas ou oblongas, ápice agudo ou obtuso, glândulas punctiformes; pétalas 2,5-5,0× 1,0-1,5 cm, oblongas, apículo e glândulas ausentes, amarelas; estames 8-14, livres ou irregularmente agrupados, filetes $0,2-0,4 \mathrm{~cm}$ compr.; ovário $0,2-0,4 \mathrm{~cm}$ compr., ovóide ou elipsóide, tricarpelar, estiletes 3 , 0,5-1,0 cm compr., estigmas capitados. Cápsula 0,4-0,7 cm compr., ovóide ou cilíndrica, marrom, de comprimento maior ao das sépalas. Sementes 0,5-0,8 mm compr., amarelas.

Material selecionado: BRASIL. Paraná: Antonina, 2/I/1996, fl. fr., Hatschbach 64029 (MBM).

Nome popular: orelha-de-gato (Rodríguez Jiménez 1980).

Hypericum mutilum subsp. mutilum apresenta distribuição nos Estados do Paraná, Santa Catarina, Rio Grande do Sul, São Paulo, Minas Gerais e Rio de Janeiro. No Estado do Paraná, ocorre na FOD, tendo sido coletada apenas no município de Antonina. Ervas heliófitas de campos secos, e ruderais, até $50 \mathrm{~m}$ de altitude. É uma espécie de fácil identificação por apresentar hábito herbáceo, 0,8-0,15 m de altura, folhas ovaladas ou suborbiculares, com o ápice arredondado ou obtuso, membranáceas, pétalas menores que o comprimento das sépalas, e estames 8-14, livres ou irregularmente agrupados. Floresce e frutifica de dezembro a abril.

10. Hypericum piriai Arechav., Anales Mus. Nac. Montevideo 3: 108. 1898.

Tipo: Uruguai, Pão de Açúcar, Castillo de Piriápolis, Arechavaleta 564, novembro de 1898, fl. fr. (Holótipo MVM, n.v.).

Sinonímia: ver Robson (1987) e Rodríguez Jiménez (1980).

\section{Fig. 61-67}

Erva anual ou perene, com base lignificada, 0,08-0,35 m alt., ereta; caule ramificado desde a base, pardo ou marrom, córtex esfoliante ou não, entrenós 0,6-2,2 cm compr.; folhas isomórficas, livres, perpendiculares ao caule, não imbricadas, 2,0-2,9× 0,1-0,2 cm, lineares, ápice agudo, base truncada, coriáceas, pouco pálidas na face abaxial, glândulas punctiformes em toda a lâmina, principalmente na face adaxial, venação hifódroma, margens revolutas, não colenquimatosas e escuras. Inflorescência em cima axilar ou terminal, sem ramificação lateral, 2-7-flora; pedicelo $0,2-0,6 \mathrm{~cm}$; brácteas 1,2-1,4 $\mathrm{cm}$ compr., lanceoladas, ápice agudo, glândulas punctiformes; flores 1,6-2,0 cm diâm.; sépalas 0,9-0,35×0,1-0,2 cm, desiguais, imbricadas, lanceoladas, ápice agudo, glândulas punctiformes e lineares; pétalas 1,6-2,8× 0,5-0,9 cm, oblongo-obovadas, apículo agudo, glândulas ausentes, amarelas; estames 30-63, 3-fasciculados, filetes $0,7-1,0 \mathrm{~cm}$ compr.; ovário $0,5-0,7 \mathrm{~cm}$ compr., ovóide, tricarpelar, estiletes 3, 0,5-0,7 cm compr., estigmas capitados. Cápsula 0,6-1,4 cm compr., elipsóide, negra, de comprimento menor ao das sépalas. Sementes 0,8-1,3 mm compr., negras.

Material selecionado: BRASIL. Paraná: Guarapuava, 16/II/1949, fl. fr., Brade 19643 (RB); Palmeira, 15/XI/1972, fl., Hatschbach 30628 (MBM); Ponta Grossa, Parque Estadual Vila Velha, 3/XI/1928, fl., fr., Hoehne s.n. (SP); idem, Buraco do Padre, 24/XI/1989, fl. fr., Silva \& Nicolack 732 (MBM); idem, Furnas, 1/X/1965, fl. fr., Hatschbach 12854 (MBM); idem, Passo do Pupo, 8/IX/1967, Hatschbach 17129 (MBM).

Nome popular: orelha-de-gato (Rodríguez Jiménez 1980).

Hypericum piriai apresenta distribuição nos três Estados da Região Sul do Brasil. No Estado do Paraná, ocorre na Estepe Gramíneo-Lenhosa, como espécie 
heliófita de solos arenosos secos ou úmidos, até $1.100 \mathrm{~m}$ de altitude. Caracteriza-se como pequena erva ereta, delicada, 0,08-0,35 $\mathrm{m}$ de altura, folhas 2,0-2,9× $0,1-0,2 \mathrm{~cm}$, lineares, ápice agudo, base truncada, margens revolutas, inflorescência de 2-7 flora, flores 1,6-2,0 cm de diâmetro, estames 30-60, 3-fasciculados, cápsula e sementes negras. Floresce de setembro a março e frutifica de outubro a abril.
11. Hypericum rigidum A. St.-Hil., Fl. Bras. Mer. 1: 336. 1828.

Tipo: Brasil, Paraná, próximo a Curitiba, Saint Hilaire 1631 pro parte, 1816-1821 (Holótipo P, n.v.).

Sinonímia: ver Robson (1990).

Fig. 68-75

Subarbusto ou arbusto $0,3-1,5 \mathrm{~m}$ alt., ereto ou decumbente; caule ramificado desde a base, marrom

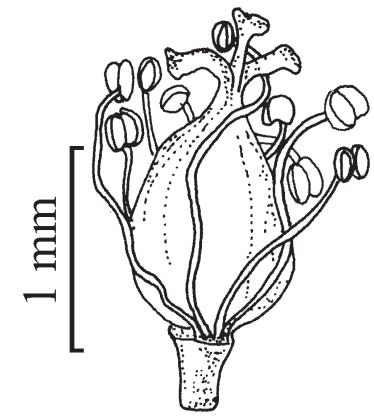

59

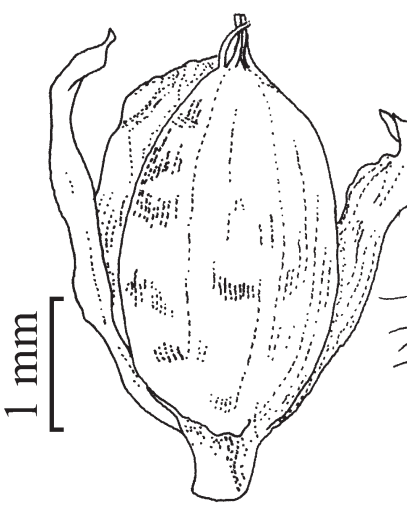

60

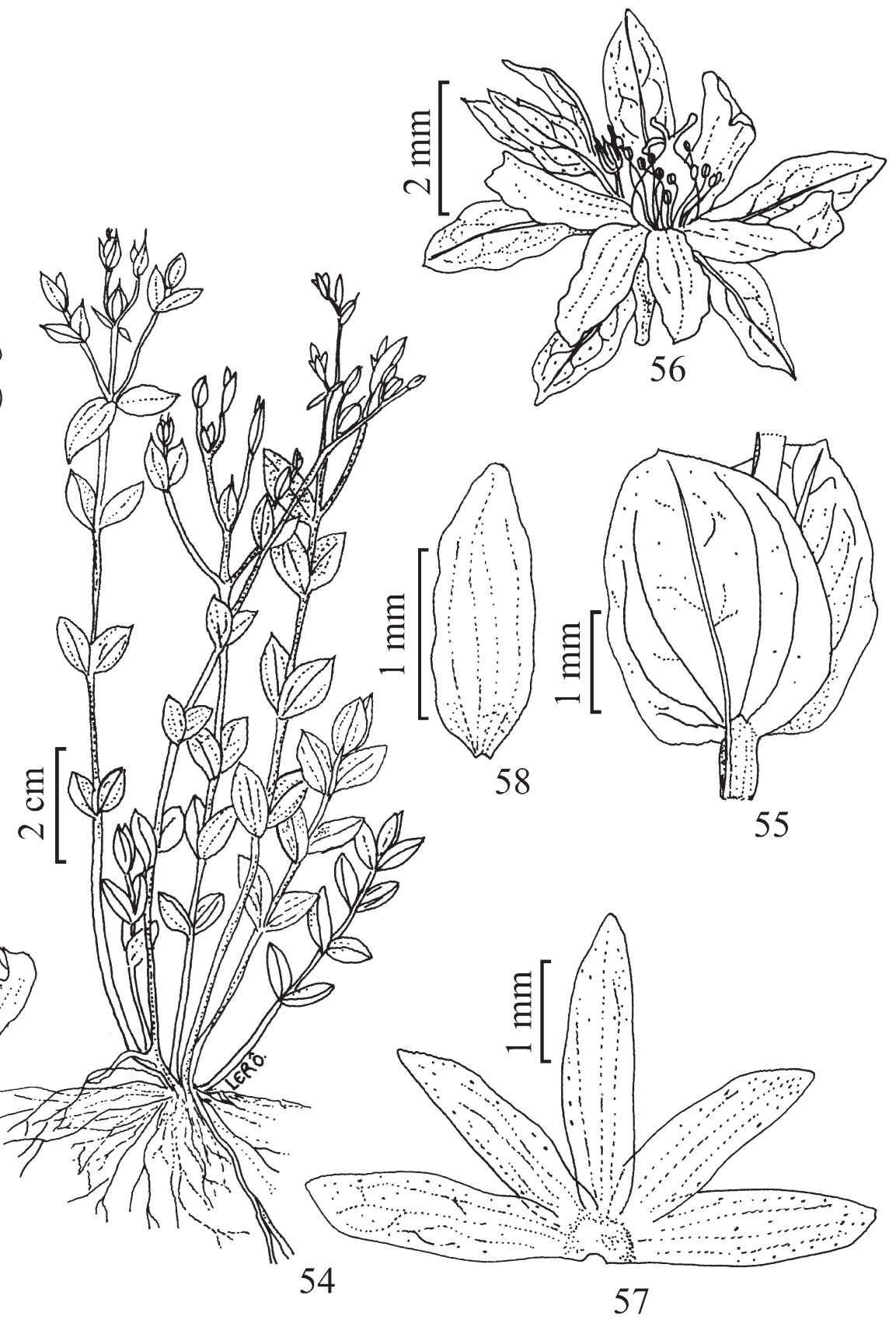

57

Figuras 54-60. Hypericum mutilum L. subsp. mutilum. 54. Hábito. 55. Detalhe do caule com folhas. 56. Flor. 57. Cálice. 58. Pétala. 59. Androceu e gineceu. 60. Cápsula (Hatschbach et al. 56101). 
ou marrom-avermelhado, córtex esfoliante, entrenós 0,3-2,0 cm compr.; folhas isomórficas, livres, perpendiculares ao caule, não imbricadas, 3,0-6,0× 0,7-1,0 cm, estreitamente elípticas, oblongas, lanceoladas ou ovalado-oblongas, ápice agudo, acuminado ou arredondado, base truncada ou convexa, coriáceas, face abaxial pardo-esverdeada ou avermelhada, glândulas punctiformes proeminentes na face abaxial, venação broquidódroma, margens planas

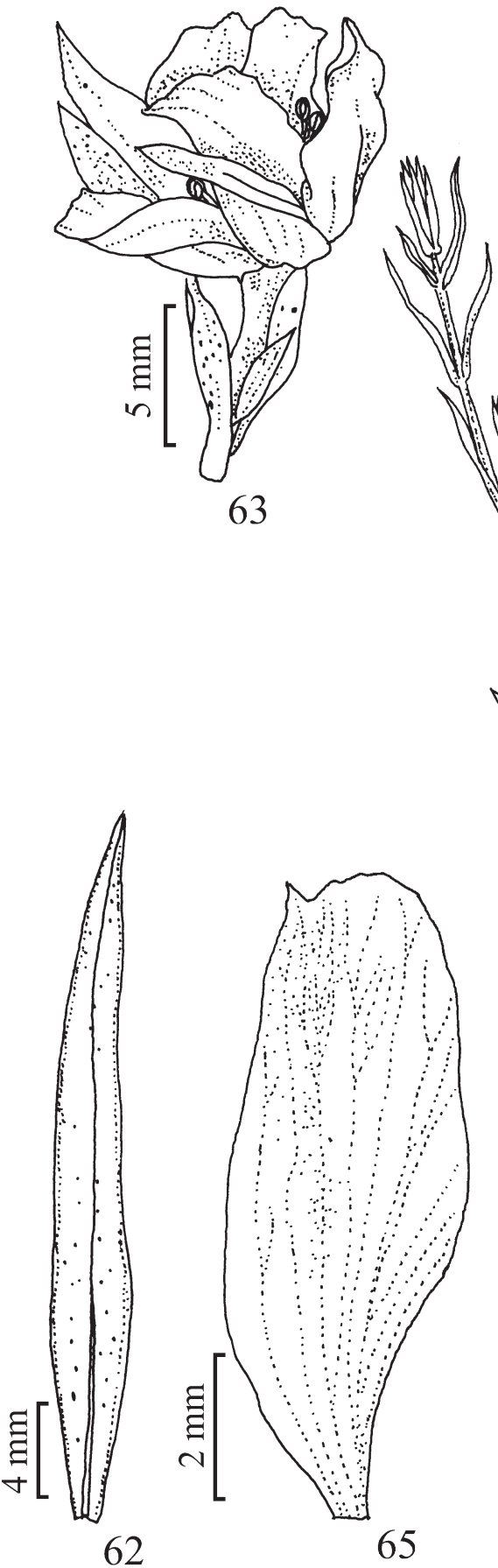

61 ou revolutas, não colenquimatosas e escuras. Inflorescência em cimas dicotômicas terminais ou pseudo-dicotômicas, às vezes com ramificação lateral, 3-5-flora; pedicelo 0,5-1,0 cm compr.; brácteas 0,4-0,7 cm compr., lanceoladas, ápice agudo, glândulas punctiformes; flores $0,7-1,3 \mathrm{~cm}$ diâm.; sépalas $0,7-1,9 \times 0,3-0,6 \mathrm{~cm}$, iguais ou desiguais, não imbricadas, oblongas ou lineares, ápice agudo, glândulas lineares e punctiformes; pétalas $0,8-1,4 \times 0,4-0,6 \mathrm{~cm}$, oblongas ou

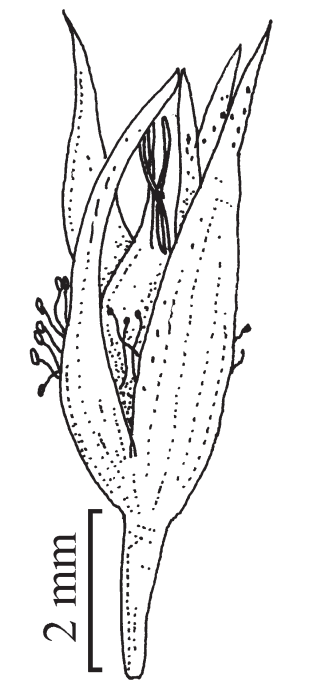

67
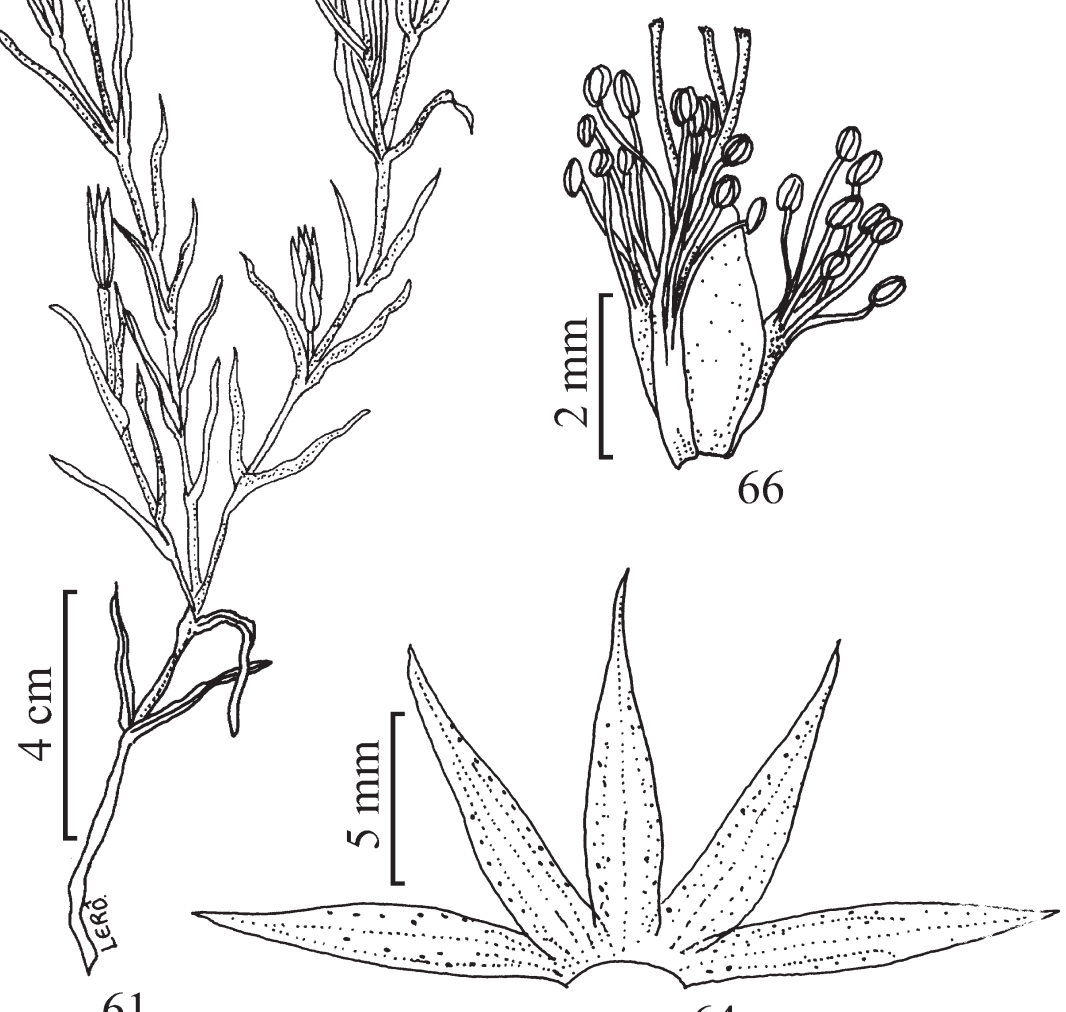

Figuras 61-67. Hypericum piriai Arechav. 61. Ramo florífero e frutífero. 62. Folha. 63. Flor. 64. Cálice. 65. Pétala. 66. Androceu e gineceu. 67. Cápsula e cálice (Hoehne s.n.). 
obovadas, apículo agudo, glândulas punctiformes, amarelas ou alaranjadas; estames $70-\infty, 5$-fasciculados, filetes $0,6-0,8 \mathrm{~cm}$ compr.; ovário $0,4-0,6 \mathrm{~cm}$ compr., ovóide, pentacarpelar, estiletes $5,0,4-0,6 \mathrm{~cm}$ compr., estigmas clavados. Cápsula $0,5-1,7 \mathrm{~cm}$ compr., elipsóide, marrom, de comprimento menor ao das sépalas. Sementes 0,6-1,2 mm compr., amarelas.

Material selecionado: BRASIL. Paraná: Balsa Nova, 14/III/1968, fl., Hatschbach 18725 (MBM); Clevelândia, 29/XII/1956, fl., Smith et al. 9581 (HBR); Curitiba, 26/XII/1973, fl. fr., Hatschbach 33599 (MBM); Guarapuava, 14/I/1983, fl., Hatschbach 46021 (MBM); Guaratuba, 10/III/1957, fl. fr., Hatschbach 5561 (HBR); Mallet, 11/XII/1966, fr., Hatschbach 15370 (UPCB); Pinhão, 10/III/1996, fl. fr., Ziller \& Tiepolo 1370 (EFC); Quatro Barras, 6/IV/1990, fl. fr., Kuniyoshi 5515 (EFC); São Mateus do Sul, 26/VI/1987, fr., Britez \& Souza 1619 (UPCB); Tijucas do Sul, 14/II/1978, fl. fr., R. Kummrow 1214 (MBM), 28/IV/1974, fl. fr., Hatschbach 34336 (MBM).

Nome popular: orelha-de-gato (Paraná, Rodríguez Jiménez 1980).

Hypericum rigidum apresenta distribuição na Região Sul do Brasil. No Estado do Paraná, ocorre na FOD, FOM e Estepe Gramíneo-Lenhosa, como espécie heliófita e seletiva higrófita. Dentre as novas propostas de classificação e revisão, discordamos de Robson (1990) que divide $H$. rigidum em quatro subespécies: $H$. rigidum A. St.-Hil. subsp. rigidum, $H$. rigidum subsp. meridionale (L.B. Sm.) N. Robson, H. rigidum subsp. sellowianum (R. Keller) N. Robson e H. rigidum subsp. bracteatum N. Robson. Verificamos, nas descrições do autor e sua chave, assim como nos exemplares, que muitos caracteres designados para a identificação infra-específica se sobrepõem, não sendo exatos para tal distinção. Assim, todos os espécimes examinados do Estado do Paraná, deste grupo, foram identificados como $H$. rigidum. Floresce de setembro a maio, e frutifica de outubro a junho.

12. Hypericum teretiusculum A. St.-Hil., Fl. Bras. Mer. 1: 331. 1828.

Tipo: Brasil, São Paulo, "in parte australi Sancti Pauli”, Saint Hilaire 1385, 1820, fl. (Holótipo P, n.v.). Sinonímia: ver Robson (1990).

Fig. 76-81

Subarbusto $0,35-1,0 \mathrm{~m}$ alt., ereto; caule simples ou ramificado desde a base, marrom-avermelhado, córtex esfoliante, entrenós $0,8-1,5 \mathrm{~cm}$ compr.; folhas isomórficas, livres ou até $1 / 3$ conatas, perpendiculares ao caule, não imbricadas, 1,0-3,3×1,0-2,4 cm, ovaladas ou elípticas, ápice agudo ou arredondado, base convexa ou cordada, coriáceas, pouco pálidas na face abaxial, glândulas punctiformes proeminentes na face abaxial, venação broquidódroma, margens planas ou revolutas, não colenquimatosas e escuras. Inflorescência em cimas dicotômicas terminais, geralmente com

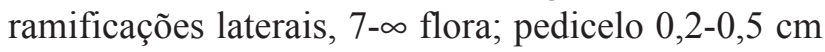
compr.; brácteas 0,4-1,0 cm compr., lineares ou lanceoladas, ápice agudo, glândulas punctiformes; flores 0,5-0,8 cm diâm.; sépalas 0,8-1,1×0,4-0,6 cm, desiguais, imbricadas, ovaladas ou lanceoladas, ápice agudo ou subacuminado, glândulas lineares; pétalas 1,5-1,7×0,6-0,9 cm, oblongas ou obovadas, apículo agudo, glândulas lineares, amarelas ou alaranjadas; estames $65-\infty, 5$-fasciculados, filetes $0,5-1,0 \mathrm{~cm}$ compr.; ovário 0,4-0,6 cm compr., ovóide ou elipsóide, pentacarpelar, estiletes 5, 0,4-0,6 cm compr., estigmas clavados. Cápsula 1,0-1,2 cm compr., ovóide ou globosa, marrom, de comprimento igual ao das sépalas. Sementes 0,8-1,2 mm compr., amarelas.

Material selecionado: BRASIL. Paraná: Candói, 23/II/1996, fl., Hatschbach et al. 64457 (MBM); Curitiba, 30/X/2001, fl. fr., Slusarski \& Cervi 202 (UPCB); Guarapuava, 29/X/1986, fl., Silva \& Ravenna 232 (MBM); Jaguariaíva, 17/I/1965, fl. fr., Smith et al.14639 (HBR); Ponta Grossa, 3/XI/2001, fl. fr., Slusarski \& Takeda 213 (UPCB); Quatro Barras, 15/I/1993, fl. fr., Kuniyoshi \& Mattei 6041 (EFC); Rio Branco do Sul, 9/II/1982, fl., Hatschbach 44560 (MBM); Tibagi, 19/XI/1969, fl. fr., Hatschbach 22953 (MBM).

Nomes populares: arruda-do-campo (Reichardt 1878; Caminhoá 1884; Corrêa 1909; Rodríguez Jiménez 1980) e orelha-de-gato (Rodríguez Jiménez 1980).

Hypericum teretiusculum apresenta distribuição conhecida restrita aos Estados do Paraná e Santa Catarina, mas provavelmente também ocorra no Rio Grande do Sul. No Estado do Paraná, ocorre na FOM, Estepe Gramíneo-Lenhosa e Savana Arbustiva. É uma espécie heliófita e indiferente às condições físicas do solo. Rodríguez Jiménez (1980) comentou que é rara no sul do Brasil, e que pode habitar ambientes permanentemente inundados. Hypericum teretiusculum é diferenciada de $H$. caprifoliatum por possuir folhas elípticas ou ovaladas, livres ou até $1 / 3$ conatas, coriáceas, e estames 5-fasciculados. Em $H$. caprifoliatum, as folhas são ovalado-deltóides ou oblongas, completamente ou $2 / 3$ contas, e os estames irregularmente fasciculados. Floresce e frutifica de setembro a abril. 
13. Hypericum ternum A. St.-Hil., Fl. Bras. Mer. 1: 330. 1828.

Tipo: Brasil, Paraná, Curitiba, Saint Hilaire 1585, março 1820. (Holótipo P, n.v.).

Sinonímia: ver Robson (1990).

Fig. 82-90
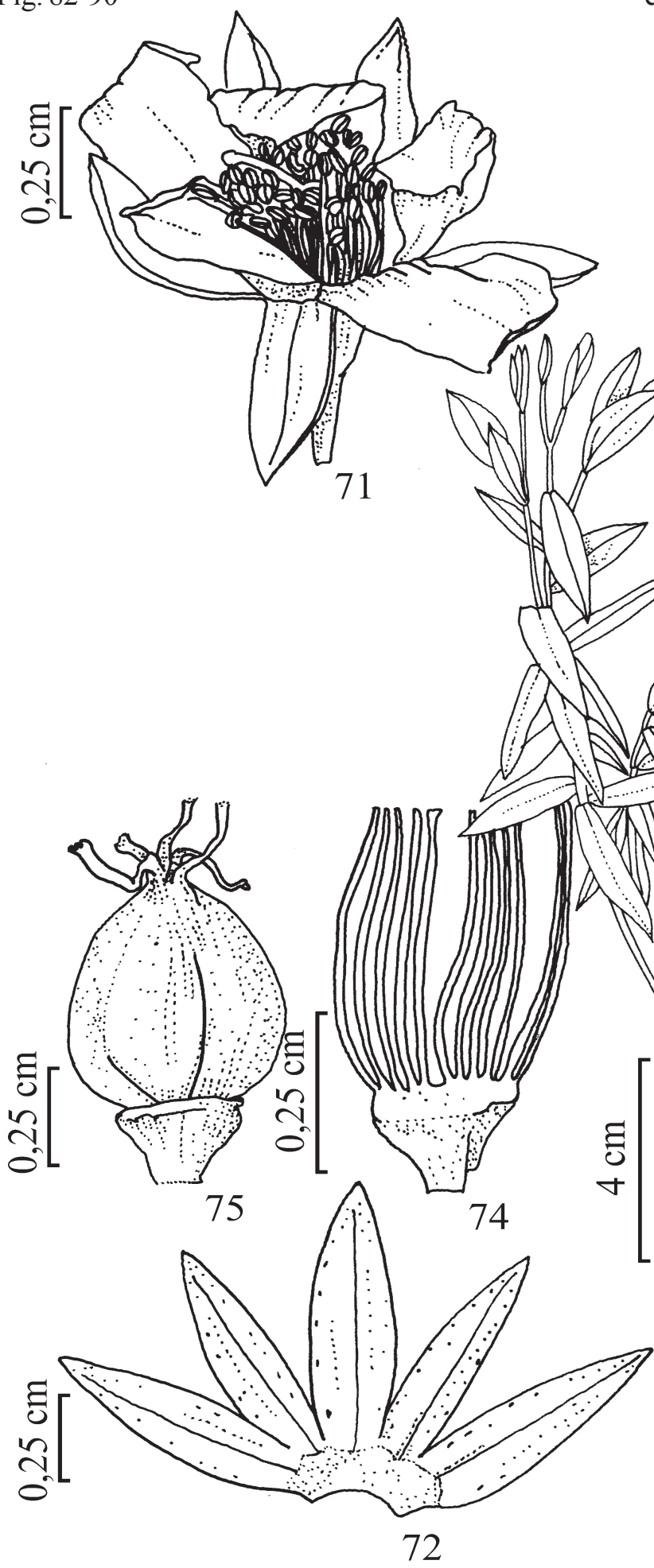

Erva anual ou perene, com base lignificada, ou subarbusto, 0,2-0,4 $\mathrm{m}$ alt., ereto, caule simples ou ramificado acima, marrom ou marrom-avermelhado, córtex esfoliante, entrenós $0,3-1,1 \mathrm{~cm}$ compr.; folhas isomórficas, todas estreitas, ou heteromórficas, livres, eretas, às vezes imbricadas, $0,6-1,3 \times 0,1-0,4 \mathrm{~cm}$, 
ovaladas, ovalado-triangulares ou lanceoladas, ápice agudo, base truncada, convexa ou subcordada, coriáceas, concolores, glândulas punctiformes proeminentes na face abaxial, venação hifódroma, margens planas ou revolutas, não colenquimatosas e escuras. Inflorescência em cimas dicotômicas terminais alongadas com ramos pouco folhosos, com ramificações laterais, 4-13-flora; pedicelo 1,0-2,0 cm compr.; brácteas $0,6-0,8 \mathrm{~cm}$ compr., ovaladas ou lineares, ápice agudo, glândulas punctiformes; flores 0,8-1,0 cm diâm.; sépalas 0,8-1,0×0,2-0,5 cm, desiguais, imbricadas, ovaladas, lanceoladas ou oblongas, ápice

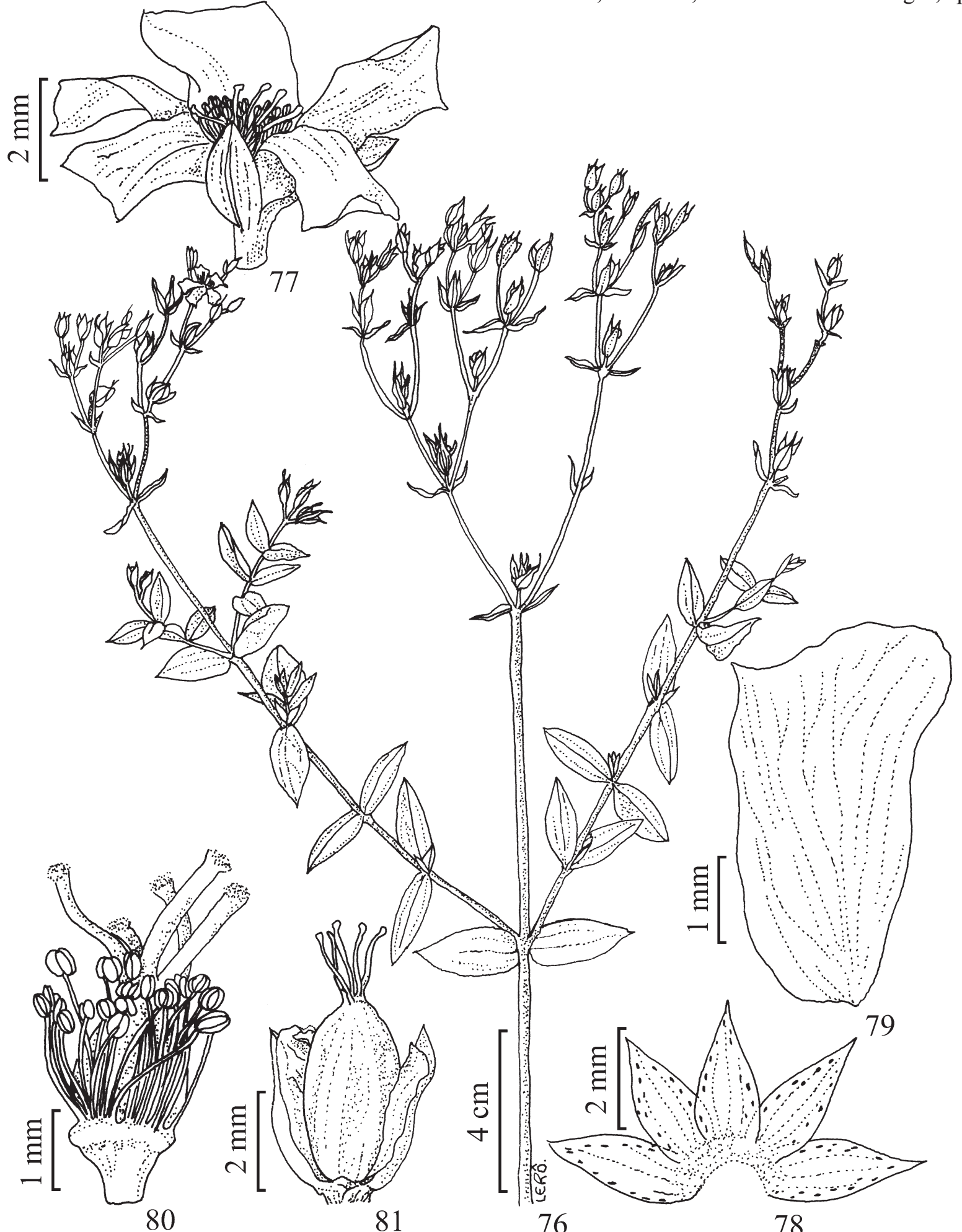

80

81 76

78

Figuras 76-81. Hypericum teretiusculum A. St.-Hil. 76. Ramo florífero e frutífero. 77. Flor. 78. Cálice. 79. Pétala. 80. Androceu e gineceu. 81. Cápsula em formação (Slusarski \& Cervi 202). 


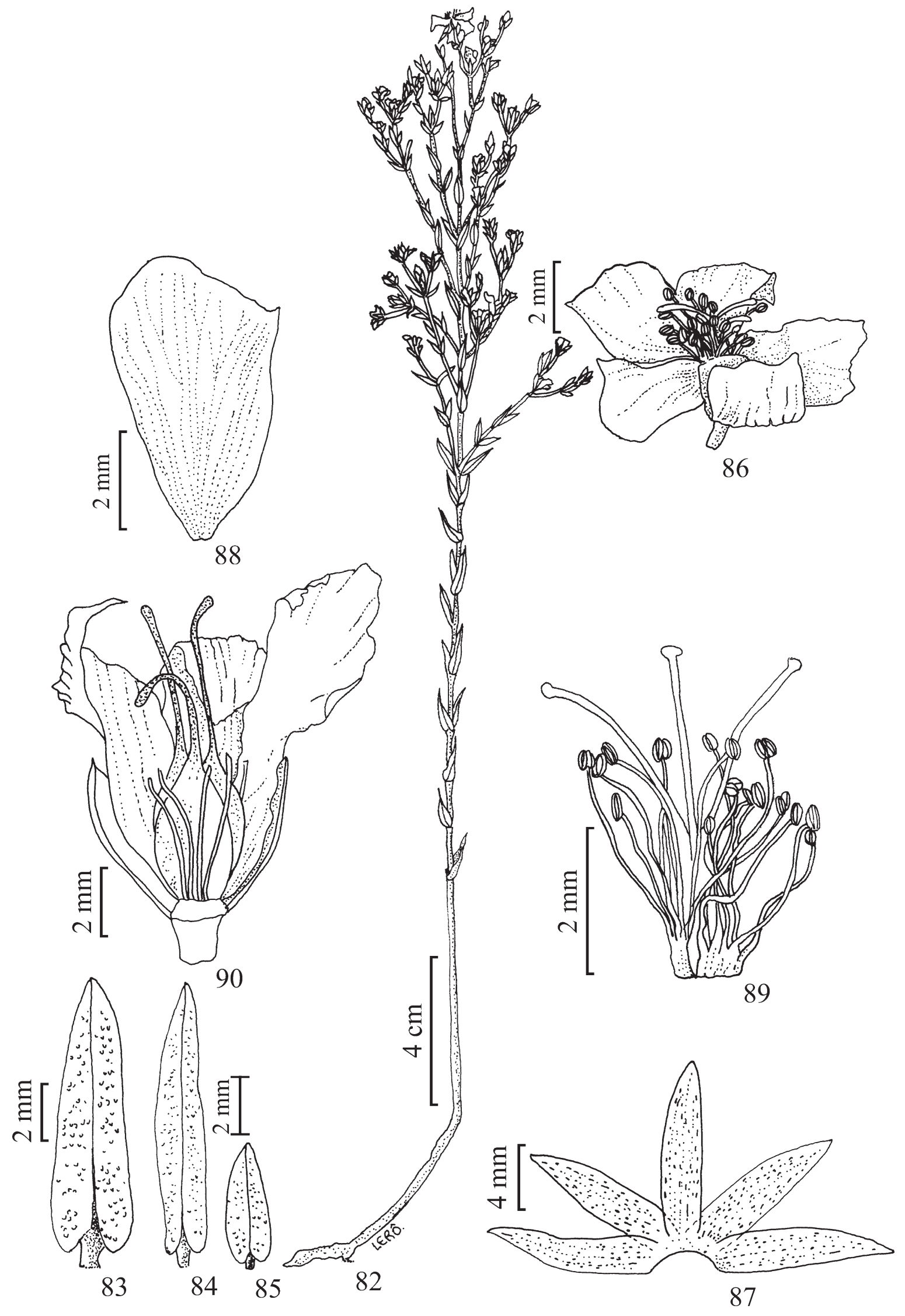

Figuras 82-90. Hypericum ternum A. St.-Hil. 82. Hábito. 83. 84. 85. Folhas. 86. Flor. 87. Cálice. 88. Pétala. 89. Androceu e gineceu. 90. Cápsula em formação (Cordeiro \& Hatschbach 465). 
agudo, glândulas punctiformes; pétalas 1,3-1,7× 0,5-0,9 cm, oblongas ou obovadas, apículo agudo, glândulas punctiformes amarelas ou alaranjadas; estames $45-63,3$ ou 4-fasciculados, filetes $0,4-0,6 \mathrm{~cm}$ compr.; ovário 0,3-0,4 cm compr., ovóide ou subgloboso, tricarpelar, estiletes 3, 0,4-0,7 cm compr., estigmas capitados. Cápsula e sementes não vistos.

Material selecionado: BRASIL. Paraná: Almirante Tamandaré, 10/I/1967, fl., Hatschbach 15652 (MBM); Balsa Nova, 12/X/1999, fl., Dunaiski Junior \& Amaral 1375 (HFIE); Campo Largo, 6/XI/2001, fl., Slusarski et al. 215 (UPCB); Lapa, 4/XI/1966, fl., Hatschbach 15227 (MBM); Palmeira, 5/XII/2001, fl., Slusarski et al. 220 (UPCB), 18/XII/1987, fl., Cordeiro \& Hatschbach 465 (MBM); Ponta Grossa,18/XI/1989, fl., Cervi et al. 2861 (MBM); Rio Negro, 2/X/1960, fl., Hatschbach 7325 (MBM).

Nomes populares: milfacadas e alecrim-bravo (Paraná).

Hypericum ternum apresenta distribuição nos Estados do Paraná, Rio Grande do Sul, São Paulo e Minas Gerais. Embora, até o presente, não tenha sido registrada para Santa Catarina, é provável a sua ocorrência neste Estado. No Estado do Paraná, ocorre na FOM e Estepe Gramíneo-Lenhosa, como espécie heliófita e seletiva sub-xerófita, entre 800 e $1.600 \mathrm{~m}$ de altitude. Robson (1990) relatou que morfotipos de $H$. ternum, considerados mais primitivos, ocorrem nos Estados de Minas Gerais e São Paulo. Estes morfotipos possuem as folhas próximas à inflorescência ovaladas ou ovaladotriangulares, mas as folhas próximas à base do caule lineares ou linear-lanceoladas. Porém, no Estado do Paraná, há uma tendência para folhas isomórficas pequenas, as quais permitem que a margem seja revoluta; neste caso, o ramo principal forma, ocasionalmente, folhas 3-verticiladas (o epíteto específico faz alusão a esta característica). Floresce e frutifica de outubro a janeiro.

\section{Agradecimentos}

Aos curadores dos herbários citados, pela consulta ou envio do material botânico; à CAPES, pela bolsa concedida.

\section{Referências bibliográficas}

APG II. 2003. An update of the Angiosperm Phylogeny Group classification for the orders and families of flowering plants. APG II. Botanical Journal of the Linnean Society 141: 399-436.

Barroso, G.M.; Guimarães, E.F.; Ichaso, C.L.F.; Costa, C.G. \& Peixoto, A.L. 1978. Sistemática de Angiospermas do Brasil. v.1. São Paulo, Universidade de São Paulo.

Bittrich, V. 2003. Clusiaceae. Pp. 45-62. In: M.G.L. Wanderley; G.J. Shepherd; A.M. Giulietti \& T.S. Melhem (eds.). Flora Fanerogâmica do Estado de São Paulo. v. 3. São Paulo, Editora da Universidade de São Paulo, FAPESP.

Caminhoá, J.M. 1884. Elementos de Botânica. v. 6. Rio de Janeiro, Typographia Nacional.

Ceballos, E.R. 1995. Flora del Valle de Lerma. Clusiaceae Lindley (= Guttiferae A. Juss.). Aportes Botanicos de Salta - Ser. Flora 3(14): 1-9.

Corrêa, M. 1909. Flora do Brasil: algumas plantas úteis, suas aplicações e distribuição geográfica. Rio de Janeiro, Typographia da Estatística.

Cronquist, A. 1981. An integrated system of classification of flowering plants. New York, Columbia University Press.

Cronquist, A. 1988. The evolution and classification of flowering plants. 2 ed. New York, The New York Botanical Garden.

Engler, A. 1893. Guttiferae. Pp. 194-242. In: A.Engler \& K. Prantl (eds.). Die Natürlichen Pflazenfamilien. v.3, pt. 6. Berlin, W. Engelmann.

Hatschbach, G.G. \& Ziller, S.R. 1995. Lista vermelha de plantas ameaçadas de extinção no Estado do Paraná. Curitiba, Secretaria do Meio Ambiente.

Holmgren, P.K. \& Holmgren, N.H. Index Herbariorum on the Internet. Disponível em <http://www.nybg.org/bsci/ ih.ih.html>. (Acesso em: 5/06/2006).

Judd, W.S.; Campbell, C.S.; Kellog, E.A.; Stevens, P.F. 1999. Plant systematics. A phylogenetic approach. Sunderland, Sinauer Associates.

Lawrence, G.H.M. 1977. Taxonomia das plantas vasculares, v. 2. Lisboa, Fundação Caulouste Gulbenkian.

Reichardt, H.W. 1878. Hypericaceae. Pp. 180-212. In: C.F.P. Martius \& A.C. Eichler (eds.). Flora Brasiliensis. v.12, pt. I. Monachii et Lipsiae, Verlag von J. Cramer.

Robson, N.K.B. 1990. Studies in the genus Hypericum L. (Guttiferae) 8. Sections 29. Brathys (part 2) and 30.Trigynobrathys. Bulletin of the Natural History Museum, Botany Series 20(1): 1-151.

Roderjan, C.V.; Kuniyoshi, Y.S. \& Galvão, F. 1993. As regiões fitogeográficas do estado do Paraná. Acta Florestalina Brasiliensis 1: 1-5.

Rodríguez Jiménez, C. 1980. Hipericáceas. Pp. 1-34. In: R. Reitz (ed.). Flora Ilustrada Catarinense. parte 1, fasc. Hipe. Itajaí, Herbário Barbosa Rodrigues. 
Saint Hilaire, J. 1805. Exposition des families naturelles et de la germination des plantes: lês Hypericées. Paris, Vez Truttel et Würtz.

Saint Hilaire, A.F.C.P.; Jussieu, A.H.L. \& Cambessedes, J. 1824. Flora Brasiliae Meridionalis 1(7). Paris, Biblioplan.
Smith, L.B. 1958. Botany: notes on South American phanerogams, II. Journal of the Washington Academy of Sciences 48(10): 310-314.

Takhtajan, A.L. 1980. Outline of classification of flowering plants (Magnoliophyta). The Botanical Review 46(3): 1-271.

Wettstein, R. 1944. Tratado de Botânica Sistemática. 4 ed. Barcelona, Labor. 